Review

\title{
Biotechnological Utilization with a Focus on Anaerobic Treatment of Cheese Whey: Current Status and Prospects
}

\author{
Aspasia A. Chatzipaschali and Anastassios G. Stamatis *
}

Mechanical Engineering Department, Polytechnic School, University of Thessaly, Volos 38334, Greece; E-Mail: asixp@hotmail.com

* Author to whom correspondence should be addressed; E-Mail: tastamat@uth.gr; Tel.: +30-24210-74077; Fax: +30-24210-74085.

Received: 30 May 2012; in revised form: 9 August 2012 / Accepted: 5 September 2012 /

Published: 10 September 2012

\begin{abstract}
Cheese whey utilization is of major concern nowadays. Its high organic matter content, in combination with the high volumes produced and limited treatment options make cheese whey a serious environmental problem. However, the potential production of biogas (methane), hydrogen or other marketable products with a simultaneous high COD reduction through appropriate treatment proves that cheese whey must be considered as an energy resource rather than a pollutant. The presence of biodegradable components in the cheese whey coupled with the advantages of anaerobic digestion processes over other treatment methods makes anaerobic digestion an attractive and suitable treatment option. This paper intends to review the most representative applications of anaerobic treatment of cheese whey currently being exploited and under research. Moreover, an effort has been made to categorize the common characteristics of the various research efforts and find a comparative basis, as far as their results are concerned. In addition, a number of dairy industries already using such anaerobic digestion systems are presented.
\end{abstract}

Keywords: cheese whey; biotechnology; anaerobic digestion; biogas production; COD removal; high strength wastewater

\section{Nomenclature}

$\begin{array}{ll}\mathrm{AD} & =\text { Anaerobic Digestion. } \\ \mathrm{BOD} & =\text { Biological (Biochemical) Oxygen Demand. } \\ \mathrm{BOD}_{5} & =\text { Five day Biological (Biochemical) Oxygen Demand. } \\ \mathrm{COD} & =\text { Chemical Oxygen Demand. }\end{array}$




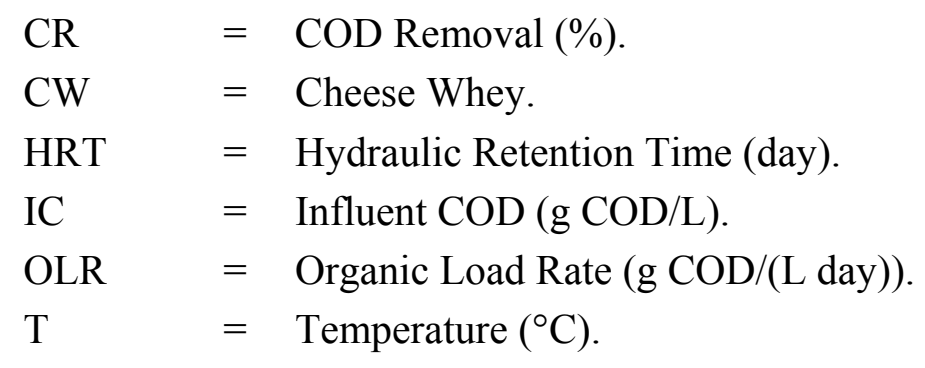

\section{Abbreviations}

$\mathrm{AAFEB}=$ Anaerobic Attached Film Expanded Bed.

$\mathrm{ABR}=$ Anaerobic Bio film Reactor.

$\mathrm{AF} \quad=$ Anaerobic Filter.

AHR $=$ Anaerobic Hybrid Reactor.

AMMBR $=$ Anaerobic Moving Biofilm Reactor.

$\mathrm{AnRBC}=$ Anaerobic Rotating Biological Contact Reactor.

$\mathrm{AP}=$ Anaerobic Pond.

$\mathrm{ARBCR}=$ Anaerobic Rotating Biological Contact Reactor.

ASBBR = Anaerobic Sequencing Batch Biofilm Reactor.

ASBR $=$ Anaerobic Sequencing Batch Reactor.

CSTR $=$ Continuously Stirred Tank Reactor.

DFFR $=$ Downflow Fixed Film Reactor.

DSFFR $=$ Downflow Stationary Fixed Film Reactor.

DUHR $=$ Downflow-Upflow Hybrid Reactor.

EPFAUF $=$ Ecological Pretreatment Followed by Anaerobic Upflow Filter.

FBR $=$ Fluidized Bed Reactor.

FFR $=$ Fixed Film Reactor.

HAR $=$ Hybrid Anaerobic Reactor.

HBR $=$ Hybrid Bed Reactor.

$\mathrm{MAB}=$ Multichamber Anaerobic Bioreactor.

NMABR $=$ Novel Moving Anaerobic Biofilm Reactor.

NMR $=$ Novel Multiplate Reactor.

$\mathrm{RBCR}=$ Rotating Biological Contact Reactor.

SDFA $=$ Semi-continuous Digester and chemical Flocculant Addition.

SMFBR $=$ Sub-Merged Fixed Bio film Reactor.

TSMAMD $=$ Two Stage Mixed Anaerobic Membrane Digester.

UAF $=$ Upflow Anaerobic Filter.

UAFFR $=$ Upflow Anaerobic Fixed Film Reactor.

UAPBR $=$ Upflow Anaerobic Packed Bed Reactor.

UAR $=$ Unmixed Anaerobic Reactor.

UASB $=$ Upflow Anaerobic Sludge Blanket.

UASFF $=$ Upflow Anaerobic Sludge Fixed Film Reactor.

UFFR $=$ Upflow Fixed Film Reactor. 
UFFLR $=$ Upflow Fixed Film Loop Reactor.

UHR $=$ Upflow Hybrid Reactor.

\section{Introduction}

During the last few decades, there has been a growing interest in alternative forms of energy. This is the result of increased demands for energy in combination of the rise in the cost of the available fuels. Furthermore, the successive population increase and the industrialization of societies have resulted in the degradation of various ecosystems on which human life relies. For this reason in the modern industrial society, the proper treatment of industrial effluents before their discharge, in order to prevent the pollution of the ground and water resources (oceans, lakes, rivers) is especially important. The liquid effluents coming from dairy industries and cheese dairies represent one of the most important industrial pollutants [1].

Effluents that come from cheese factories can be divided into two basic categories. The washing and pasteurization waters, mixed with detergents and milk remnants of from the machinery piping belong in the first category. In the second category we have cheese whey $(\mathrm{CW})$. The effluents of the first category have low organic loads and are usually treated onsite in suitable aerobic treatment units. Although the volume of $\mathrm{CW}$ accounts for about $1 / 3$ of the total effluents, it has high organic load (high concentrations of COD and BOD) making it too polluted for its direct disposal on land or in water resources to be allowed [2-7]. Treatment of wastewaters coming from cheese factories and mainly $\mathrm{CW}$, is based on physicochemical and/or biological methods. However, the reagent cost in physicochemical methods is very high and the removal of soluble COD is poor, therefore biological processes are often preferred [8] with anaerobic digestion (AD) being the most suitable for such high organic loading effluents [9]. The major advantages of this process compared to other treatment methods are: low cost, high energy efficiency and process simplicity [10]. Furthermore, this method can achieve an adequate removal of BOD and COD from CW and the methane production is close to the theoretical yield [11].

In the literature there are reviews focusing on cheese whey as a resource to produce added value products (lactose, proteins, ethanol, biogas, etc.) and presenting the different production methods [12-18]. Some other reviews focus on the AD of dairy industry effluents including CW [2,19,20], the two phase anaerobic treatment of various wastewaters [21,22] and the AD of various industry effluents [23]. The above reviews constituted useful starting points for this paper, which aims to provide an update on the research and technology status concerning the use of $\mathrm{CW}$, with a focus on $\mathrm{AD}$ systems for removing the organic load content (COD) of $\mathrm{CW}$ and producing biogas. More specifically, this paper presents the general characteristics of the effluents of $\mathrm{CW}$ and gives a brief description of different methods for managing and using CW as a resource for producing added value products. Then, it presents in detail the most representative AD systems used on a laboratory or pilot scale for biogas (methane) production and CW pollutant load reduction. An effort has been made (for the first time to our knowledge) to reduce common characteristics of these systems and establish a comparative basis, as far as their results are concerned. The related technology status is expressed by corresponding diagrams of COD 
removal rate versus Hydraulic Retention Time (HRT) and Organic Load Rate (OLR). Finally, some existing applications of industrial scale AD systems are described.

\section{Composition of Cheese Whey}

Cheese whey is a liquid byproduct of the cheese making process that contains most of the water soluble components and water present in milk [24-26]. More specifically, after casein curd separates from the milk, following coagulation of the casein proteins through the action of chymosin or mineral/organic acid, the remaining watery and thin liquid is called whey [17,27]. It has a yellow/green color or sometimes even a bluish tinge, depending on the quality and type of milk used. The composition of $\mathrm{CW}$ depends also on the quality and the composition of evaluated milk and other parameters such as the cheese production techniques used, the amount of yeast, the acid used for coagulation, the quality of these, the period and temperature of coagulation, etc. [28]. CW can come from any kind of milk. In Western societies cows' milk is the most popular, while in other regions of the world goat, sheep and even camel milk are used in the local dairy industries [17].

This byproduct represents $85 \%-95 \%$ of the milk volume and retains about $55 \%$ of the milk nutrients [3]. The most abundant of these nutrients are lactose $(45-50 \mathrm{~g} / \mathrm{L})$, soluble proteins $(6-8 \mathrm{~g} / \mathrm{L})$, lipids $(4-5 \mathrm{~g} / \mathrm{L})$ and mineral salts $(8 \%-10 \%$ of the dry extract). The mineral salts are mainly $\mathrm{NaC} 1$ and $\mathrm{KC1}$ (more than 50\%), calcium salts (mainly phosphate) and others. $\mathrm{CW}$ also contains appreciable quantities of lactic and citric acid, non-protein nitrogen compounds (like urea and uric acid) and B group vitamins $[4,15,29,30]$.

According to the production process and the coagulation of casein, the $\mathrm{CW}$ is divided into two categories: acidic whey, which has a $\mathrm{pH}$ of less than $5(\mathrm{pH}<5)$, and sweet whey with a $\mathrm{pH}$ value between 6 and $7(6<\mathrm{pH}<7)$ [31]. The acidic $\mathrm{CW}$ usually contains fewer proteins and because of the acidic flavor and high salt content, it is used with limitations for alimentation [13,15,29]. The main differences between these two types of $\mathrm{CW}$ are the content of mineral elements, the acidity and the composition of the fraction of whey proteins. Table 1 presents the typical composition of sweet and acid whey.

Table 1. Typical composition of sweet and acid whey [30,32].

\begin{tabular}{ccc}
\hline Components & Sweet whey $(\mathbf{g} / \mathbf{L})$ & Acid whey $(\mathbf{g} / \mathbf{L})$ \\
\hline Total solids & $63-70$ & $63-70$ \\
Lactose & $46-52$ & $44-46$ \\
Proteins & $6-10$ & $6-8$ \\
Calcium & $0.4-0.6$ & $1.2-1.6$ \\
Phosphate & $1-3$ & $2-4.5$ \\
Lactate & 2 & 6.4 \\
Chloride & 1.1 & 1.1 \\
\hline
\end{tabular}

The whey which is produced from cheese coagulated with rennet is low in acidity, while the one coming from the production of fresh acidic cheeses like ricotta and cottage cheese is medium acid or acid CW [30]. 
$\mathrm{CW}$ is characterized as a high strength organic pollutant with high BOD and COD values in the range of 40,000-60,000 and 50,000-80,000 ppm, respectively [33,34]. Lactose is largely responsible for the high oxygen demand of BOD and COD, as more than $90 \%$ of whey $\mathrm{BOD}_{5}$ is due to this substance [34,35]. Furthermore, 97.7\% of the total COD was accounted for by lactose as well as by lactate, proteins and fats [29,34,36,37]. On the other hand, protein recovery reduces the COD of the whey by only about $10,000 \mathrm{ppm}[15,38]$ or $12 \%$ [3]. The organic load of $\mathrm{CW}$ as given from various literature sources is shown in Table 2.

Table 2. Organic load of cheese whey.

\begin{tabular}{ccc}
\hline Components & Value & References \\
\hline & $40,000-60,000 \mathrm{ppm}$ & {$[34]$} \\
BOD $_{\mathbf{5}}$ & $30,000-50,000 \mathrm{ppm}$ & {$[15,39]$} \\
& $>30,000 \mathrm{ppm}$ & {$[17]$} \\
\hline \multirow{3}{*}{ COD } & $50,000-80,000 \mathrm{ppm}$ & {$[34,40]$} \\
& $60,000-80,000 \mathrm{ppm}$ & {$[15]$} \\
& $60,000-100,000 \mathrm{ppm}$ & {$[39]$} \\
\hline
\end{tabular}

In addition to the above components, some works have found that $\mathrm{CW}$ also contains some heavy metals in low quantities. In a tank with a mix of raw whey and industrial washing waters the elements $\mathrm{Cd}, \mathrm{Cr}, \mathrm{Cu}, \mathrm{Hg}, \mathrm{Pb}$ and $\mathrm{Zn}$ were found [41]. Moreover, in a recent research [42], quantities of $\mathrm{Al}, \mathrm{Cd}$ and $\mathrm{Pb}$ were observed in $\mathrm{CW}$ powder. The presence of heavy metals in $\mathrm{CW}$ enhances its highly polluting load because of the serious toxic effects caused by heavy metals in organisms.

It has been estimated that, the world whey production is over than 160 million tons per year $[17,38,43]$. Approximately half of this total $\mathrm{CW}$ production is discarded directly to the environment, representing a significant loss of resources and a major pollution problem. To make one kilo of cheese, nine kilos of CW are produced [15]. Its disposal affects the physical and chemical soil structure, with result in decreased crop yields, while the release into water resources reduces aquatic life, by depleting the dissolved oxygen [15,30]. Recent research in Greece (the Vouraikos River) shown that the water pollution and the ecological risk to aquatic life are very high since the concentration of the disposal untreated $\mathrm{CW}$ in the aquatic ecosystem was five times more than permitted limits [44]. The high pollutant load of $\mathrm{CW}$, along with its continuously increasing production ( $>2 \%$ every year, [45]), lead to a serious management problem.

\section{Cheese Whey Management}

According to Siso [15], only $50 \%$ of the total produced quantity of $\mathrm{CW}$ is treated and turned into various food products. This percentage is expected to increase as a result of continued research efforts in the field of whey utilization coupled with the pressure on casein and cheese producers by relevant legislation concerning the disposal of liquid effluents [38]. At the same time, new products and technologies are being developed for the treatment of $\mathrm{CW}$ wastewaters. In European Union, it has been mentioned that $45 \%$ of the $\mathrm{CW}$ that is treated and transformed into different food products is used 
directly in liquid form, $30 \%$ in powder form, $15 \%$ as lactose and non-lactose byproducts and the rest as CW protein concentrates [46,47].

According to Mawson [13], the different ways of disposal or use of CW could be divided into three main categories: (1) Direct use or disposal, where the CW is used with very little or no further processing. This category includes the traditional use of CW as animal feed and the direct use of the whole or deproteinated CW as a component of food or drinks; (2) Direct stabilization, where the CW is treated by physical or chemical ways in order to make it more stable towards microbial degradation. The techniques used include: protein recovery with ultrafiltration or heat denaturizing, concentration by reverse osmosis and/or with evaporation, crystallization or drying of lactose; (3) Conversion processes, where the lactose is converted into other compounds through the activity of microorganisms (biotransformation) or through chemical reactions.

The direct addition of liquid CW into drinking water for animals is limited, because of the high quantity of lactose and mineral levels. Its use as agricultural fertilizer has a disadvantages due to the high amount of salt that it leaves behind. Besides, the transport of liquid CW is very expensive [15] and therefore a large proportion of the produced $\mathrm{CW}$ is dried in order to produce powdered CW $[46,48,49]$. In this form, the $\mathrm{CW}$ can be kept fresh for a longer period of time and its handling and transportation are also easier. Powdered CW is used mainly as animal feed and in smaller quantities can be used in foodstuffs for human consumption, like ice cream, bread, sweets, sauces, dairy products, etc. [15,38].

The initial phase in most $\mathrm{CW}$ utilization processes consists of the recovery of the protein fraction. The CW proteins, which represent $15 \%-22 \%$ of milk proteins, are considered beneficial for health and are characterized by high nutritional value and therapeutic potential [17,38,50,51]. The major whey proteins are: $\alpha$-lactalbumin, $\beta$-lactoglobulin, bovine serum albumin (BSA) and bovine IgG. In addtion there are also minor whey proteins such as lactoperoxidase, lacto (trans) ferrin and other minor compounds. Riechel et al. [52], detected bovine lactoferrin, that exists in very small concentration in $\mathrm{CW}$, by capillary electrophoresis. Through separation of the $\mathrm{CW}$ proteins from whey by ultrafiltration, diafiltration or processing of membranes, whey protein concentrates-WPC - which are used in the food industry $[15,17,48,53]$ or Whey Protein Isolate-WPI-are produced. The WPC contains $30 \%-90 \%$ proteins, while the WPI contains more than $90 \%$ proteins in the dry matter [18]. The WPC is free of salts, so it is suitable for all kinds of human foods, even for dietetic or baby food [46]. Other non-food uses of whey proteins deal with specific properties of single proteins used in cosmetology and pharmacology [18]. The physical and functioning properties of whey proteins are solubility, viscosity, cohesion and adhesion, emulsifying properties, water sorption and gel-forming properties [54]. The different uses of whey proteins are based on these properties (for more details see [18]).

During the milk processing for WPC production, permeate (large quantities of streams rich in lactose) is produced, which continues to be a lactose-containing pollutant representing more than $70 \%$ of milk whey. Lactose, as stated earlier, represents a noteworthy pollutant load, therefore, the disposal of permeate creates quite similar problems to the disposal of raw CW [53]. The solubility and the sweetness of lactose is low compared to other sugars, like glycose, galactose, fructose and sucrose $[55,56]$. Most of the lactose products are recovered from the whey or whey permeate by crystallization procedures (for details see $[49,55,57])$. Lactose is used mainly as a component of food, infant formulae and as a filler or coating agent for tablets in the pharmaceutical industry. However, it has rather limited application in food products because of its low digestibility and poor solubility (ability to crystallize) [18]. Lactose is used 
also as substrate in the synthesis of derivatives such as lactulose, lactitol, lactobionic acid, lactosyl urea, galacto-oligosaccharides and hydrolysed lactose syrup [18,49,55,56].

Hydrolyzed lactose solutions possess greater sweetening power than lactose and are used in the confectionary and ice cream industries replacing saccharose or starch syrup $[15,56]$. Technology for the production of hydrolysed lactose syrup is well developed and is used, for instance, to produce dairy products suitable for lactose-intolerant individuals [55]. Chemical hydrolysis is possible at low $\mathrm{pH}(<1.5)$ and high temperature (more than $150{ }^{\circ} \mathrm{C}$ ), but the enzymatic hydrolysis using Aspergillus and Kluyveromyces enzymes is usually the method of choice $[38,49,55,56]$. Lactose in whey or permeate may be used as a substrate for the elaboration of valuable compounds by fermentation. Some well-known examples are the production of ethanol [38], single cell protein (SCP) production in yeast-based bioprocesses and biogas (methane) and hydrogen production. Other bioproducts are: organic acids (acetic, propionic, lactic, citric, gluconic, itaconic and gibberellic), amino acids (glutamic, lysine and threonine), vitamins (B12 and B2 or cobalamins and riboflavin respectively), polysaccharides (xanthan gum, dextran, phosphomannan, pullulan and gellan), oils (lipids), enzymes (b-galactosidase and polygalactorunase) and other compounds (fructose diphosphate, 2,3-butanediol, calcium, magnesium acetate, ammonium, lactate butanol and glycerol [15,18,49,56,58]. In Figure 1, the various products resulting from the processing of whey lactose are shown.

Figure 1. Applications of CW-lactose [18].

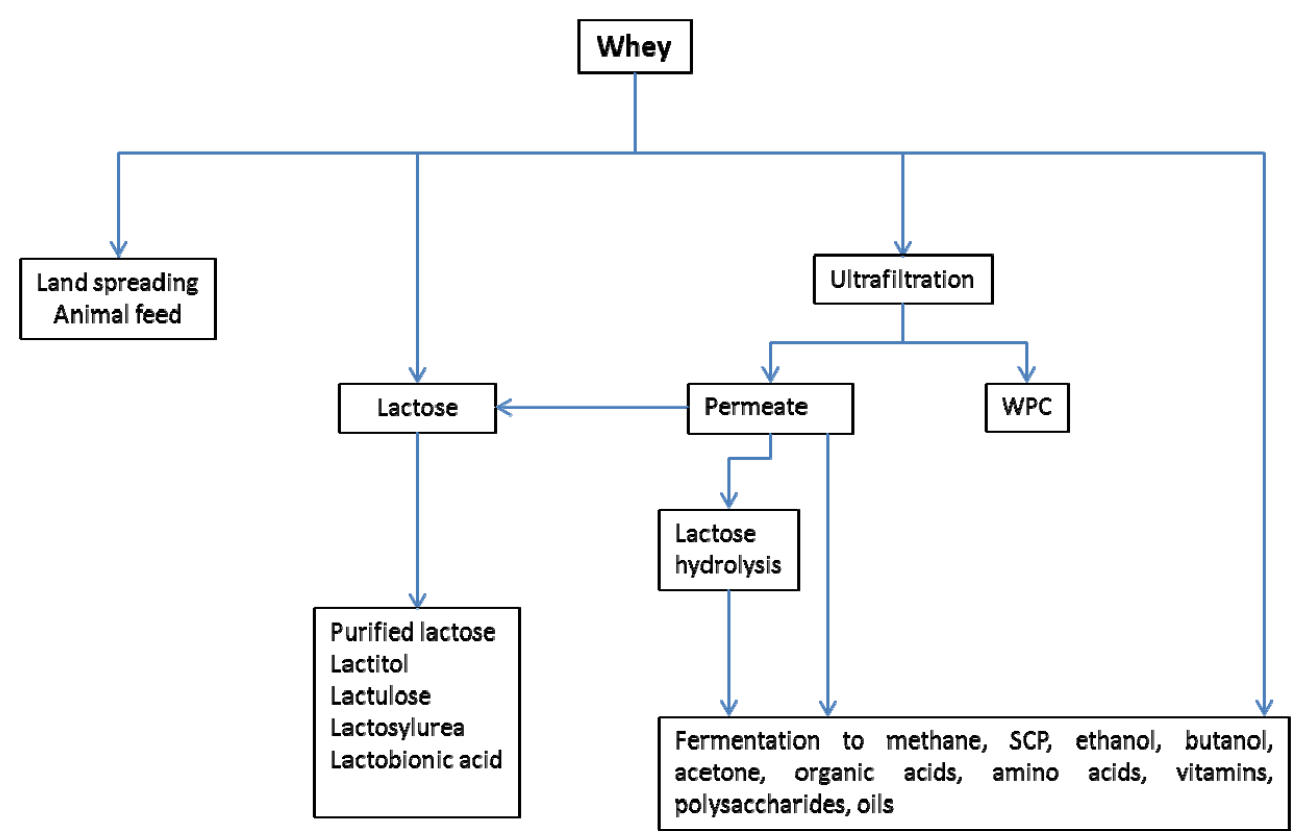

(SCP: Single cell protein and WPC: whey protein concentrates).

In a recent experimental research project conducted by Antonopoulou et al. [59], it was proved that diluted $\mathrm{CW}$ can be an energy source for the production of electrical energy using a two-chamber mediator-less microbial fuel cell (MFC; H-type), replacing the typical substrate of lactose and glucose. The maximum power density obtained using diluted CW (normalized to the geometric area of the anodic electrode), was $18.4 \mathrm{~mW} / \mathrm{m}^{2}$, which is equivalent to a current density $80 \mathrm{~mA} / \mathrm{m}^{2}$ and voltage of MFC $0.23 \mathrm{~V}$. The coulombic efficiency was only $1.9 \%$, which could be attributed to biochemical oxidation of the organic substratum by the indigenous non-electrogenic microbial consortium 
contained in the raw wastewater. Optimization and further development by the improvement of MFC design and with pretreatment of the $\mathrm{CW}$ (sterilization or pasteurization) might increase both density and couloumbic efficiency making the procedure economically viable [60]. Finally, the economic and environmental importance of $\mathrm{CW}$ utilization for the production of bio-hydrogen has recently been identified and there is a growing research interest focusing on this subject [29,60-66].

\section{Use of Anaerobic Digestion Systems—Production of Biogas and Removal COD}

In cases where cheese production plants have growing disposal problems and cannot afford the high investment costs for whey valorization technologies (such as whey protein and lactose recovery, spray drying, etc.), the biological treatment is an imperative process to reduce the pollutant load. Because of the high organic content of $\mathrm{CW}, \mathrm{AD}$ constitutes an excellent treatment method [10]. This fact has also been proved by Spachos and Stamatis [67], through exergy and economic analysis of a modeled CW treatment AD system.

The AD process includes degradation and stabilization of organic matters by microorganisms under anaerobic conditions and leads to biogas (a mixture of carbon dioxide and methane) and biomass formation $[23,40,68]$. In particular, with regard to $\mathrm{CW}$, this complex process consists of three sequential steps: hydrolysis of lactose (and proteins), fermentation and methanogenesis [18,69]. AD involves several mixed bacteria species. According to Audic et al [18], about $90 \%$ of hydrolyzed organic matter is converted into biogas in the methanogenesis process. It is estimated that one liter of $\mathrm{CW}$ can produce 45 liters of biogas containing 55\% methane and the expected COD removal is $80 \%$. For each liter of CW 20 liters of $\mathrm{CH}_{4}$ can be produced, which are equivalent to 700 Btu of energy production [11]. However, despite the energy potential and waste reduction, the use of AD is not widespread in the dairy industries, mainly due to the slow reaction rates (high HRT) and the relative process instability in conventional reactors [4].

Malaspina et al. [70], asserted that $\mathrm{CW}$ is quite a difficult substrate to treat anaerobically (especially in highly loaded reactors) because of its high organic content, low bicarbonate alkalinity (50 meq/L), tendency to acidify rapidly, granulation difficulties and its tendency to produce an excess of viscous exopolymeric materials of probable bacterial origin that reduce significantly the sludge settling ability and could be reason for washout of the biomass. However, the development of some technologies and systems of $\mathrm{AD}$ (which will follow) for the $\mathrm{CW}$ treatment, prove that it is a worthy and valuable source of energy. Table 3 presents different biogas production systems using CW which have been studied on a laboratory or pilot scale while Figure 2 illustrates the maximum COD removal (\%) versus HRT for these systems.

From Figure 2 it becomes clear that it is quite difficult to assess the effectiveness of the used systems, at least with respect to the superiority of any particular technology. Various types of reactors have been used, ranging from simple to more complex types such as UASB (for more details see [19]). In general, it is difficult to compare systems operated in different laboratories, not only because of the possible differences in the anaerobic sludge characteristics [4], but also because of the differences in operating parameters (such as temperature, $\mathrm{pH}$, OLR, total solids and volatile fatty acids content, toxicity, HRT, inoculums type) and the composition of the AD effluent. 
Table 3. Cheese whey treatment systems.

\begin{tabular}{|c|c|c|c|c|c|c|c|c|c|}
\hline Waste & Reactor & IC & pH & Biogas $/ \mathrm{CH}_{4}$ yield & HRT & OLR & $\mathbf{T}$ & $\mathbf{C R}$ & Ref. \\
\hline $\mathrm{CW}$ & DFF & 66 & - & $0,28 \mathrm{~m}^{3} \mathrm{CH}_{4} / \mathrm{kg} \mathrm{COD}$ rem & 4.9 & 13 & - & 75 & [71] \\
\hline $\mathrm{CW}$ & DFF & 66 & - & $0,34 \mathrm{~m}^{3} \mathrm{CH}_{4} / \mathrm{kg} \mathrm{COD}_{\mathrm{rem}}$ & 6.6 & 8.3 & - & 76 & [71] \\
\hline $\mathrm{CW}$ & $\mathrm{AF}$ & - & - & - & 4 & - & $30-21-12.5$ & $92-85-78$ & {$[72,73]$} \\
\hline $\mathrm{CW}$ & UASB & 28.7 & 7.18 & $9.57 \mathrm{~L} \mathrm{CH}_{4} / \mathrm{L}$ feed/day & 5 & 5.96 & 33 & 98 & [74] \\
\hline Sour(acidic)whey & UFFLR & 79 & 6.7 & $5.6 \mathrm{~m}^{3} / \mathrm{m}^{3}$ day & 5 & 14 & 35 & 95 & [75] \\
\hline CW high strength & UASB & 77 & - & - & 11.6 & 28.5 & 35 & 95 & [76] \\
\hline $\mathrm{CW}$ & UASB & 28.8 & 7.15 & - & 5 & 5.96 & 33 & 98 & [77] \\
\hline $\mathrm{CW}$ & UAR* & 72.2 & 4.5 & - & 20 & 3.5 & 35 & 36 & [78] \\
\hline Deproteinated CW & DSFFR & 13 & & - & 5 & 2.6 & 35 & 88 & [79] \\
\hline Strength lactic casein whey permeate & FBR & 7 & 4.3 & $0.396 \mathrm{~m}^{3} \mathrm{CH}_{4} / \mathrm{kg} \mathrm{COD}_{\text {rem. }}$ & 0.4 & 7.7 & 35 & 90 & [80] \\
\hline Sweet whey powder & AAFEB & 5 & 7 & - & 0.65 & 10 & 35 & 92 & {$[11]$} \\
\hline Cheddar CW & AnRBC* & 64 & - & - & 5 & 10.2 & 35 & 96 & [81] \\
\hline $\mathrm{CW}$ & SDFA & 69.8 & - & - & 4.3 & 16.1 & - & 99 & [82] \\
\hline $\mathrm{CW}$ & $(\mathrm{SBR})^{* * *}$ & 3.9 & 7 & - & 3 & 1.04 & 20 & 97 & [83] \\
\hline Whey in a dried form & AHR (R1) & 1 & $7-8$ & $0.69\left(\mathrm{CH}_{4}\right.$ yield $)$ & 0.75 & 1.3 & 20 & 80 & [84] \\
\hline Whey in a dried form & AHR (R2) & 10 & $7-8$ & $0.55\left(\mathrm{CH}_{4}\right.$ yield $)$ & 0.75 & 13.3 & 20 & 90 & [84] \\
\hline Cheese was/ter & UASB & 2.05 & 6.7 & $0.321 \mathrm{CH}_{4} / \mathrm{gCODelim}$. & 0.07 & 31 & 35 & 90 & [85] \\
\hline $\mathrm{CW}$ & AHR & 10 & - & $0.354\left(\mathrm{CH}_{4}\right.$ yield $)$ & 1.7 & 6.11 & 35 & 97 & [86] \\
\hline (Salty) CW & RBCR & 30 & 7 & $4.1 \mathrm{~L} / \mathrm{L}_{\text {digester }} /$ day & 3 & 10 & 37 & 85 & [87] \\
\hline (Salty) CW & $(\mathrm{MB})$ & - & - & $3.2 \mathrm{~L} / \mathrm{L}_{\text {digester }} /$ day & 2 & - & 37 & 83 & [88] \\
\hline $\mathrm{CW}$ & UF (SFR \& MFR) & 9 & $4-7$ & - & 0.33 & 35 & - & 87 & [89] \\
\hline $\mathrm{CW}$ & HBR & 22 & - & - & 2 & 11 & - & 95 & [90] \\
\hline $\mathrm{CW}$ & EPFAUF)* & 20 & 7 & - & 5 & 4 & $34-36$ & 98 & {$[4]$} \\
\hline $\mathrm{CW}$ & ASBR & - & - & - & 0.33 & - & $28-32$ & 90 & [91] \\
\hline Raw CW & TSMAMD* & 68.6 & $7.9-8.5$ & $>0.70\left(\mathrm{CH}_{4}\right.$ yield $)$ & 4 & 19.78 & 37 & 98.5 & [34] \\
\hline $\mathrm{CW}$ & UASB* & 58.4 & $7-8$ & $0.77\left(\mathrm{CH}_{4}\right.$ yield $)$ & 2.46 & 24.6 & - & 97 & [10] \\
\hline $\mathrm{CW}$ & DUHR & 68 & - & - & 7 & 10 & - & 97 & {$[70]$} \\
\hline $\mathrm{CW}$ & UAFFR & 70 & - & $0.72\left(\mathrm{CH}_{4}\right.$ yield $)$ & 2 & 35 & 37 & 81 & [92] \\
\hline
\end{tabular}


Table 3. Cont.

\begin{tabular}{|c|c|c|c|c|c|c|c|c|c|}
\hline Waste & Reactor & IC & $\mathbf{p H}$ & Biogas $/ \mathrm{CH}_{4}$ yield & HRT & OLR & $\mathbf{T}$ & $\mathbf{C R}$ & Ref. \\
\hline $\mathrm{CW}$, butter, fresh milk & $\mathrm{AHR}^{*}$ & 5.34 & 5.22 & $0.28-0.35\left(\mathrm{CH}_{4}\right.$ yield $)$ & 1.9 & 2.82 & 35 & 97 & [93] \\
\hline CW \&diluted poultry manure & CSTR & 91 & - & $2.2 \mathrm{~L} / \mathrm{L}_{\text {reactor }} /$ day & 18 & 4.9 & 35 & 77 & [39] \\
\hline Whey mix \& cow manure & $\mathrm{AD}^{1}$ & - & - & - & 14 & - & 35 & 74 & {$[94]$} \\
\hline $\mathrm{CW}$ & UASB* & 10.82 & - & - & 0.75 & 15 & $34-36$ & 99 & {$[95]$} \\
\hline CW\&dairy manure & CSTR & 29 & - & - & 10 & - & 34 & 54 & {$[28]$} \\
\hline $\mathrm{CW}$ & FBR & $0.8-10$ & - & - & $0.1-0.4$ & $6-40$ & 35 & $63-87$ & [96] \\
\hline Deprotainated CW & UASB & 11 & - & - & 1.5 & 7.1 & 35 & 94 & {$[97]$} \\
\hline $\mathrm{CW}$ & $\mathrm{AP} * *$ & 4.4 & - & - & 8 & 0.55 & - & 96 & [98] \\
\hline $\mathrm{CW}$ & CSTR \& UAF* & - & - & $0.55 \mathrm{~m}^{3} / \mathrm{kg} \mathrm{COD}$ rem. & 4 & - & - & 95 & [99] \\
\hline $\mathrm{CW}$ & 2 CSTRs* & 10 & - & - & 10 & 0.97 & 55 & 96.4 & [100] \\
\hline $\mathrm{CW}$ & UASFF & 57 & - & 3.75 L/day & 2 & 25 & 36 & 97.5 & {$[40]$} \\
\hline Diluted CW & UASB & 37 & 7.2 & - & 6 & 6.2 & 35 & 98 & [9] \\
\hline $\mathrm{CW}$ & NMR & 42.5 & - & - & 2.83 & 15 & 34 & 92 & [101] \\
\hline $\mathrm{CW}$ & $\mathrm{AF}$ & 8.1 & - & - & 4.3 & 1.9 & $22-25$ & 97 & {$[102]$} \\
\hline $\mathrm{CW}$ & NMABR & 10.2 & - & - & 1 & 11.3 & 35 & 89 & [103] \\
\hline $\mathrm{CW}$ & NMABR & 10.2 & $7-8$ & - & 0.6 & 15.3 & 35 & 81 & [103] \\
\hline $\mathrm{CW}$ & UAPBR & 59.4 & 6.5 & - & 0.66 & 59.28 & 25 & 94.5 & [104] \\
\hline
\end{tabular}

* Two phase anaerobic treatment; $* *$ Anaerobic-Aerobic process; $* * *$ Sequential anaerobic and aerobic step in a single digester; ${ }^{1}$ Anaerobic digester (batch, fed batch, batch). 
Figure 2. Maximum COD removal (\%) versus HRT for various $\mathrm{CW}$ treatment systems.

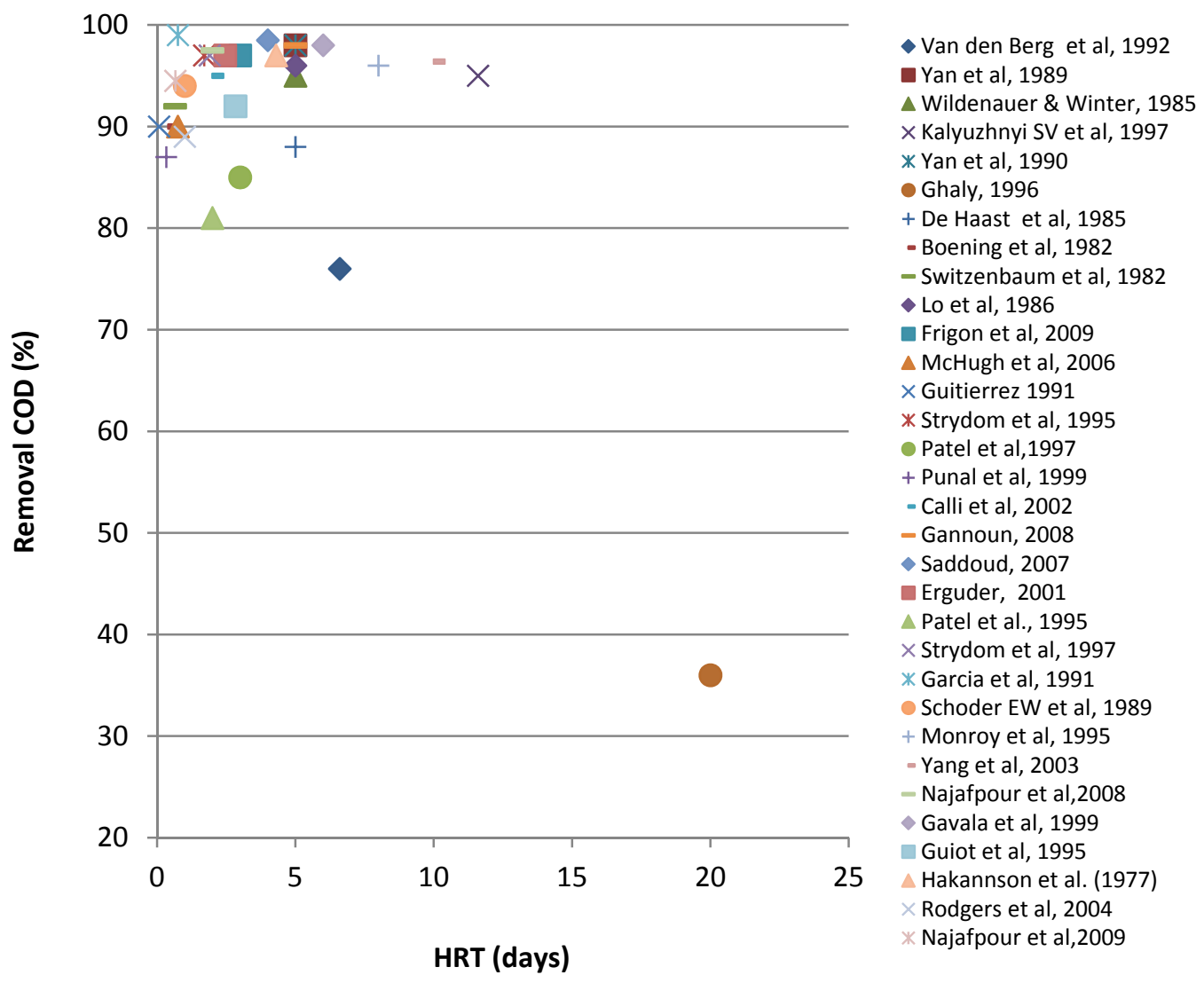

Since $\mathrm{AD}$ is a biochemical process driven by consortia of various microorganisms which are involved in the transformation of complex high-molecular-weight organic compounds into methane, any stress or disturbance on the system may lead to a change in species types and their relative population levels, which is ultimately reflected in the reactor performance. Therefore, the organic material added as inocula in the fermentative organic substrate is one of the most important factors affecting $\mathrm{AD}$ of organic waste. High microbial loading inocula material needs to be added in the mixture of biomass when starting up the anaerobic digester. The inocula have significant effects on biogas productions (for more details see [105]). The selection of the appropriate inoculum is very important and depends on the composition of the substrate $(\mathrm{C} / \mathrm{N} / \mathrm{P}$, alkanity). For example, Gannoun et al. [4], reported that for $\mathrm{AD}$ of ecological pretreatment $\mathrm{CW}$ with optimum composition for the $\mathrm{AD}$ system the inocula was obtained from an active biogas digester of fruit and vegetable waste treatment [106].

The composition of the effluent of the $\mathrm{AD}$ is also important for either direct discharge or the following AD. However, only few works on CW AD treatment can be found in literature $[75,91,107]$, giving the detailed composition of the effluent of the AD. Most of the works reported only indicative data for the effluent (such as COD ,VFA concentration, etc.). In Table 4 are listed some of the reported works on cheese whey AD treatment along with the type of inoculum used and the AD effluent composition characteristics. 
Table 4. Inocula and effluent concentration of CW AD treatment.

\begin{tabular}{|c|c|c|c|c|}
\hline Waste & Reactor & Inoculum & Effluent & Ref. \\
\hline $\mathrm{CW}$ & UASB & $\begin{array}{l}\text { Seed sludge from AnRBC used for } \\
\text { treatment a mixture of } \mathrm{CW} \text { and manure }\end{array}$ & $\begin{array}{l}\text { COD: } 457 \mathrm{mg} / \mathrm{L}, \mathrm{pH}: 7.18 \text {, } \\
\text { VFA: } 18 \mathrm{mg} / \mathrm{L}\end{array}$ & [74] \\
\hline Sour (acidic) whey & UFFLR & Sewage sludge & COD: $3.9 \mathrm{~g} / \mathrm{L}$ & {$[75]$} \\
\hline CW (high strength) & UASB & $\begin{array}{l}\text { Dispersed sludge from anaerobic lagoon } \\
\text { treating meet industry wastewater }\end{array}$ & $\mathrm{VFA}<0.5 \mathrm{gCOD} / \mathrm{L}$ & {$[76]$} \\
\hline $\mathrm{CW}$ & UASB & $\begin{array}{l}\text { Seed sludge from AnRBC used for } \\
\text { treatment a mixture of } \mathrm{CW} \text { and manure }\end{array}$ & $\begin{array}{l}\text { COD: } 457 \mathrm{mg} / \mathrm{L} \\
\mathrm{pH}=7.18, \mathrm{VFA}: 18 \mathrm{mg} / \mathrm{L}\end{array}$ & {$[77]$} \\
\hline $\mathrm{CW}$ & UAR* & $\begin{array}{l}\text { Seed material from unmixed An. } \\
\text { Digester operating on dairy manure }\end{array}$ & $\begin{array}{l}\text { COD: } 33.02 \mathrm{~g} / \mathrm{L}, \\
\text { Volatile solids } \\
\text { concentration: } 17.9 \mathrm{~g} / \mathrm{L}\end{array}$ & [78] \\
\hline $\mathrm{CW}$ & $(\mathrm{SBR}) * * *$ & $\begin{array}{l}\text { Biomass for the inoculum came from a } \\
\text { full scale anaer. digester treating fruit } \\
\text { processing wastewaters }\end{array}$ & $\begin{array}{l}\text { COD: } 51 \pm 56 \mathrm{mg} / \mathrm{L} \text { after } \\
\text { aerobic step }\end{array}$ & [83] \\
\hline Whey in a dried form & AHR (R1) & $\begin{array}{l}\text { Anaerobic granular sludge originating } \\
\text { from an internal circulation reactor } \\
\text { treating wastewater from a commercial } \\
\text { lactose alcohol }\end{array}$ & sCOD: $150-300 \mathrm{mg} / \mathrm{L}$ & [84] \\
\hline Whey in a dried form & AHR (R2) & $\begin{array}{l}\text { Anaerobic granular sludge originating } \\
\text { from an internal circulation reactor } \\
\text { treating wastewater from a commercial } \\
\text { lactose alcohol }\end{array}$ & $\begin{array}{l}\text { propionate: } 500 \mathrm{mg} / \mathrm{L} \text {, } \\
\text { acetate: } 100 \mathrm{mg} / \mathrm{L}\end{array}$ & [84] \\
\hline $\begin{array}{l}\text { Cheese production } \\
\text { wastewater }\end{array}$ & UASB & $\begin{array}{l}\text { Cleaning water from cheese factory } \\
\text { (cheese production waastewaters) }\end{array}$ & $\begin{array}{l}\text { acetic \& propionic acid } \\
\text { concentration: } 0.01-0.02 \\
\mathrm{mg} / \mathrm{L}, \mathrm{COD}: 65 \mathrm{mg} / \mathrm{L}\end{array}$ & {$[85]$} \\
\hline $\mathrm{CW}$ & $\begin{array}{l}\text { UF (SFR \& } \\
\text { MFR) }\end{array}$ & $\begin{array}{l}\text { Seed sludge from UAF mesophilic } \\
\text { reactor treating wastewaters from tuna } \\
\text { processing factory }\end{array}$ & $\begin{array}{l}\text { SFR COD: } 5 \mathrm{~g} / \mathrm{L} \& \mathrm{MFR} \\
\text { COD: } 2 \mathrm{~g} / \mathrm{L}\end{array}$ & [89] \\
\hline Pretreated CW & $($ EPFAUF)* & $\begin{array}{l}\text { Inoculum from an active biogas digester } \\
\text { of fruit and vegetable waste treatment }\end{array}$ & - & {$[4]$} \\
\hline $\mathrm{CW}$ & ASBR & $\begin{array}{l}\text { Inoculum from UASB treating poultry } \\
\text { slaugherhouse wastewater }\end{array}$ & - & [91] \\
\hline Raw CW & TSMAMD* & $\begin{array}{l}\text { Inoculum From full scale AD treatment } \\
\text { plant }\end{array}$ & - & [34] \\
\hline $\mathrm{CW}$ & UASB* & - & $\begin{array}{l}\text { COD: } 1.428-1.975 \\
\operatorname{mgCOD} / \mathrm{L}\end{array}$ & {$[10]$} \\
\hline $\mathrm{CW}$ & UAFFR & Inoculum from operating whey reactor & $\begin{array}{l}\text { VFA: } 0.94 \mathrm{~g} / \mathrm{L}, \\
\text { COD: } 16.4 \mathrm{~g} / \mathrm{L}\end{array}$ & [92] \\
\hline CW, butter, freshmilk & $\mathrm{AHR}^{*}$ & $\begin{array}{l}\text { Inoculum from sewage sludge, rumen } \\
\text { fluid and effluent from two other } \\
\text { mesophilic lab-scale reactor }\end{array}$ & - & [93] \\
\hline $\mathrm{CW}$ & UASB* & $\begin{array}{l}\text { Sludge from anaerobic reactor treating } \\
\text { whey in a single step }\end{array}$ & - & [95] \\
\hline
\end{tabular}


Table 4. Cont.

\begin{tabular}{lllll}
\hline Waste & Reactor & Inoculum & Effluent & Ref. \\
\hline $\mathrm{CW}$ & 2 CSTRs* & $\begin{array}{l}\text { Inoculum from municipal wastewater } \\
\text { treatment }\end{array}$ & - & {$[100]$} \\
\hline $\mathrm{CW}$ & UASFF & $\begin{array}{l}\text { Seed culture from wastewater treatment } \\
\text { plant }\end{array}$ & - & {$[40]$} \\
\hline Diluted CW & UASB & $\begin{array}{l}\text { Inoculated with anaerobic mixed liquor } \\
\text { from dairy wastewaters and glucose fed } \\
\text { digesters }\end{array}$ & COD: $5 \mathrm{~g} / \mathrm{L}$ & {$[9]$} \\
\hline
\end{tabular}

* Two phase anaerobic treatment; ***Sequential anaerobic and aerobic step in a single digester.

Depending upon different types of design criteria $\mathrm{AD}$ can be categorized into several types such as: according to feeding mode (batch, semi-batch or continuous reactors), the temperature (psychrophilic, mesophilic and thermophilic reactors), the solid content (high or low solids reactors), the complexity [single stage or two (multi) stage reactors], the shape of the reactor (horizontal and vertical), the way microorganisms are retained in the reactor (fixed film, suspended growth and hybrid), moisture in the substrate (wet or dry digestion) [108-111]. In this paper the AD categorization based on the number of $\mathrm{AD}$ phases (single/two phase $\mathrm{AD}$ system) is employed in order to present the time evolution of the different reactors and to understand more clearly the reasons for two phase AD development. Therefore, it has been decided to divide the systems into groups, according to the type (of the design) of the used reactor and to compare the papers of each group in terms of the highest COD removal rate versus HRT and OLR.

\subsection{Conventional (Single Phase) Anaerobic Treatment of Cheese Whey}

In several dairy wastewaters treatment systems, AF are often used, being suitable for effluents with low concentrations of suspended solids. Hakannson et al. [102], using AF were able to achieve a high organic removal efficiency (97\% COD removal) with an influent concentration $8,100 \mathrm{mg} / \mathrm{L}$ but at low OLR of $1.9 \mathrm{~kg} \mathrm{COD} /\left(\mathrm{m}^{3}\right.$ day), at an operating temperature of $22-25^{\circ} \mathrm{C}$. Later, Viraraghavan et al. [72,73] achieved COD removals between $78 \%$ and $92 \%$ for 4 day HRT, by using a laboratory scale plastic medium AF reactor. The temperature variation between 21 and $30^{\circ} \mathrm{C}$ had no significant effect on the startup performance of the AF treating $\mathrm{CW}$, in terms of COD removal [112].

Some of the basic problems (clogging of the filters, dead zones, etc.) during the wastewater treatment with UAF come from the excessive accumulation of biomass, which limits the efficiency of the process. In order to overcome these problems, two laboratory scale single fed (SFR) and multi fed (MFR) UAF treating CW wastewaters operated at OLR higher than $20 \mathrm{~kg} \mathrm{COD} /\left(\mathrm{m}^{3}\right.$ day) were studied and compared [89]. The feeding policy had an effect both on biomass concentration and activity. Specific activities of different trophic groups were higher in MFR. Therefore, the MFR system operation was efficient, especially at high organic loading rate and at the same time major problems inherent in this technology (filter clogging and dead zones), are avoided.

Other treatment systems use FFR. For instance, Van den Berg and Kennedy [71], used a pilot scale DFFR at an HRT of 4.9 days and at an OLR of $13 \mathrm{~kg} \mathrm{COD} /\left(\mathrm{m}^{3}\right.$ day) and achieved $75 \%$ COD removal and $0.28 \mathrm{~m}^{3} / \mathrm{kg} \mathrm{COD}$ removed methane yield. By increasing the HRT to 6.6 days and reducing OLR to 
$8.3 \mathrm{~kg} \mathrm{COD} /\left(\mathrm{m}^{3}\right.$ day) the COD removal efficiency was slightly increased (1\%) and the methane yield rose to $0.33 \mathrm{~m}^{3} / \mathrm{kg} \mathrm{COD}$ removed.

Patel et al. [92], investigated AD of high strength $\mathrm{CW}$ (70 $\mathrm{g} \mathrm{COD} / \mathrm{L})$ using an UFFR and the maximum COD removal achieved was $81 \%$ at an HRT of 2 days and with a charcoal support material. This type of reactor allows the effective digestion, both at low and high strength wastewaters (in terms of the organic materials and suspended solids) in a low HRT. The FFR was able to treat higher strength substrates (without nutrient additional and $\mathrm{pH}$ control) and had higher COD removal efficiency than FBR. However, a longer HRT (at least 5 days) is needed, in the FFR [113,114].

Rodgers et al. [103], used a novel ABR with a vertically moving bio film system, called AMMBR. At an HRT of 1 day and OLR of $11.6 \mathrm{~kg} \mathrm{COD} /\left(\mathrm{m}^{3}\right.$ day $)$, at mesophilic conditions $\left(\sim 35^{\circ} \mathrm{C}\right), 89 \% \mathrm{COD}$ removal efficiency was obtained. The decrease of HRT to 0.6 days and the increase of OLR to $15.2 \mathrm{~kg} \mathrm{COD} /\left(\mathrm{m}^{3}\right.$ day $)$, led to the reduction of COD removal efficiency by $8 \%$. The methane content in the produced biogas was $63 \%$ on average and the methane yield was $0.33 \mathrm{~m}^{3} / \mathrm{kg} \mathrm{COD}$ removed, very close to theoretical value $\left(0.35 \mathrm{~m}^{3} / \mathrm{kg} \mathrm{COD}\right.$ removed). This drop in COD removal with increase in OLR also appeared was noted in [11], where a satisfactory COD removal efficiency (61\%-92\%) achieved, using an AAFEB reactor at high organic load rate $\left[8.2-22 \mathrm{~kg} \mathrm{COD} /\left(\mathrm{m}^{3}\right.\right.$ day $\left.)\right]$ and under mesophilic conditions $\left(\sim 35{ }^{\circ} \mathrm{C}\right)$. However, increase of the influent strength from 5 to $20 \mathrm{~kg} \mathrm{COD} /\left(\mathrm{m}^{3}\right.$ day) led to a drop in the COD removal efficiency from $83 \%$ to $58 \%$. This reactor has also proved to be suitable for treatment at lower temperatures $\left(28-31^{\circ} \mathrm{C}\right)$ succeeding in satisfactory COD removal efficiency $(77 \%-93 \%)$.

A major problem during the $\mathrm{CW}$ treatment is the usage of $\mathrm{CW}$ to growth the yeast. Methods such as hydrolysis of the $\mathrm{CW}$, yeast adaptation and pressure selection are empoyed to overcome this problem. A recent research [115], found that SMFBR is also a suitable method to face this problem and to treat $\mathrm{CW}$ as well as all dairy effluents. In order to clarify some of the above discussed aspects, the COD removal efficiency rate versus $\mathrm{HRT}$ (day) and $\mathrm{OLR}[\mathrm{g} \mathrm{COD} /(\mathrm{L}$ day)] are presented in Figure 3 . It is observed that Hakannson et al. [102], achieved the highest COD removal efficiency (97\%) using AF for low strength CW treatment, at the lowest OLR compared with the other studies.

Figure 3. Maximum COD removal versus (a) HRT (day) and (b) OLR [g COD/(L day)] using anaerobic filters, fluidized bed reactors and fixed film reactors for CW treatment.

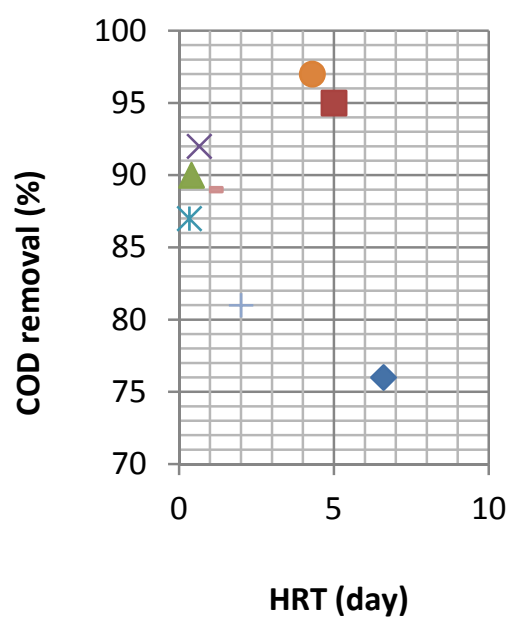

(a)

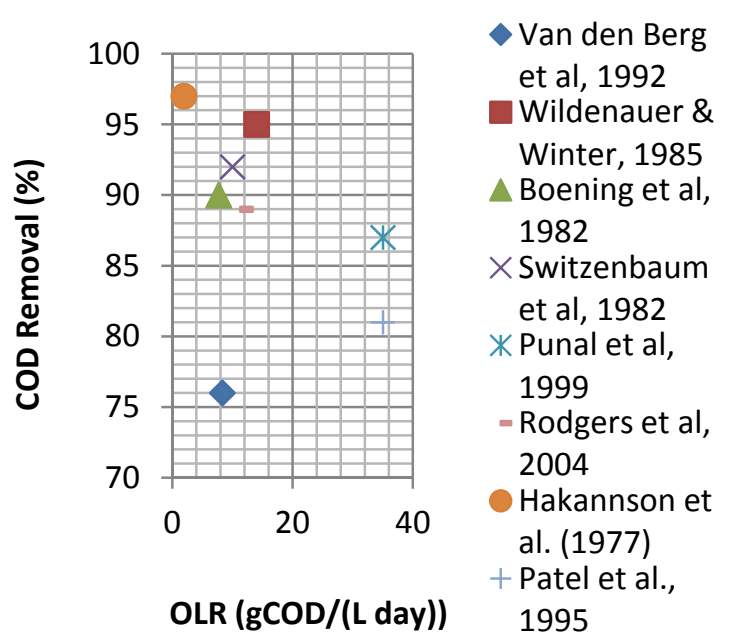

(b) 
Wildenauer and Winter [75], using UFFLR with similar HRT but at much higher influent COD and at higher OLR achieved slightly lower COD removal by $2 \%$. It is also noteworthy that Boening and Larsen [80], using FBR and Switzenbaum and Daskin [11], using AAFEB achieved slightly lower COD removal $(\sim 5 \%)$, but at a much lower HRT (about $1 / 4$ ) compared to the other two studies $[75,102]$.

The works mentioned up to this point have been carried out with $\mathrm{pH}$ adjustment ( $\mathrm{pH}$ control) in order to stabilize the operating conditions. The $\mathrm{pH}$ can be adjusted by adding bicarbonate $[116,117]$ and $\mathrm{NaOH}$ [100]. Another method of $\mathrm{pH}$ adjustment is the co-digestion of $\mathrm{CW}$ with manure (poultry, cow, etc.). Co-digestion has been proved to be possible, without addition of any chemicals, with up to $50 \%$ participation of whey (by volume) in the daily feed mixture. With this method the specific biogas production remained roughly unchanged at the various whey fractions added in the feed mixture mainly because of the lower COD of CW compared to that of manure $[28,39,94]$. The CW anaerobic treatment is affected by the drop in $\mathrm{pH}$. This effect can be handled with buffering action in a hybrid reactor, which is not possible in an UASB reactor without proper startup [20].

Due to the risk of strong acidification, the startup of the reactor is always a critical step [4]. The UASB reactor [118], can cope with preacidified CW wastewaters ( $\mathrm{pH}$ of about 4), even at elevated OLR, that eliminates the necessity of alkanity supplementation by ensuring a proper startup. The COD removal efficiency reached up to $90 \%$ at an OLR $28.5 \mathrm{~kg} \mathrm{COD} /\left(\mathrm{m}^{3}\right.$ day $)$ and $9.5 \mathrm{~kg} \mathrm{COD} /\left(\mathrm{m}^{3}\right.$ day $)$ for mesophilic $\left(\sim 35{ }^{\circ} \mathrm{C}\right)$ and psychrophilic $\left(20-30{ }^{\circ} \mathrm{C}\right)$ conditions, respectively, under a stable operation regime [76]. Further exploitation of the reactor with the designed OLR of $6.5 \mathrm{~g} \mathrm{COD} /(\mathrm{L}$ day) showed sufficient operational stability with COD removal close to $95 \%$ on the basis of total COD.

COD removal close to $90 \%$, at a high OLR of $31 \mathrm{~kg} \mathrm{COD} /\left(\mathrm{m}^{3}\right.$ day) and HRT of $1.7 \mathrm{~h}$ and methane production with an average value of $0.32 \mathrm{~L} \mathrm{CH}_{4} / \mathrm{g} \mathrm{COD}_{\text {removed }}$ was obtained for cheese production wastewater (influent COD $2.05 \mathrm{~g} / \mathrm{L}$ ) using a laboratory scale UASB reactor under stable operating conditions [85]. Increase of OLR of about $30 \%$, [higher than $45 \mathrm{~kg} \mathrm{COD} /\left(\mathrm{m}^{3}\right.$ day)] had as a result a reduction of the COD removal rate by $11 \%-26 \%$. This is a common problem in CW treatment. As the substrate loading increases the acidogenic region extends into the methanogenic region in the upper part of the reactor until the whole region becomes acidogenic, leading to the failure of the reactor [77,119].

Gavala et al.[9], using a laboratory scale UASB reactor (10 L useful volume) for cheese producing industry wastewaters (influent concentrations between 12 and $60 \mathrm{~g} \mathrm{COD} / \mathrm{L}$ ), achieved a maximum COD removal efficiency of $98 \%$ at an HRT of 6 days with an influent COD concentration of $37 \mathrm{~g} / \mathrm{L}$ [OLR $6.2 \mathrm{~g} \mathrm{COD} /(\mathrm{L}$ day)]. The increase of influent COD concentration to $42 \mathrm{~g} / \mathrm{L}$ [OLR to $7.5 \mathrm{~g} \mathrm{COD} /(\mathrm{L}$ day $)]$ led to reduction of the COD removal efficiency $(85 \%-90 \%)$. Further increase of HRT to 30-40 days and reduction of the OLR to 1.5-1.9 g COD/ (L day), led to decrease of COD removal to $81 \%$. The maximum biogas production rate, during the conducted experiment was approximately $45 \mathrm{~L}$ /day with a methane content of $68 \%-74 \%$.

Because of the instability caused by the strength of the influent in UASB reactor, the optimum influent substrate concentration for the proper system operation is determined to be between 25 and $30 \mathrm{~g} \mathrm{COD} / 1$ at an HRT of 5 days [119]. In general UASB reactors are suitable for treatment of dairy wastewaters containing high concentrations of fat and grease with COD removal of about $90 \%$, as has been reported by Cammarota et al. [120] and are the most common reactors for CW treatment, since they can treat large volumes of wastewaters in a relatively short time [2]. However, the performance of the UASB system has not been yet discussed in detail. Systematic analysis of the reactor 
characteristics such as the operation stability, HRT, sludge granulation and the sludge discharging is still necessary. One of the most serious limitations of the UASB process is the relative long time that is required for the startup and for the granulation (even several months). To overcome these limitations, a modification is required $[10,121]$. A new model UASB reactor called one dimensional dispersed plug flow model was developed by the Kalyuzhnyi et al. [122]. This model focuses on the granular sludge dynamics along the height of the reactor, based on the balance between the dispersion, sedimentation and conversion with the use of one dimensional (with regard to the height of the reactor) equations.

Figure 4 presents the technology status based on the data of the works described so far, through COD removal rate versus HRT (day) and OLR [g COD/(L day)]. It is observed that the highest COD removal was obtained both by Yan et al. [74,77] for CW treatment (influent COD concentration $28.8 \mathrm{~g} \mathrm{COD} / \mathrm{L}$ ) and Gavala et al. [9] for diluted CW treatment (influent COD concentration $37 \mathrm{~g}$ $\mathrm{COD} / \mathrm{L}$ ), proving the UASB reactors suitability to treat also high organic load raw wastewaters. In both studies there were no significant deviations regarding the influent COD concentrations as well as the OLR and the operating conditions ( $\mathrm{pH}$ and temperature).

Figure 4. Maximum COD removal versus (a) HRT (days) and (b) OLR [g COD/(L day)] using UASB reactors for CW treatment.

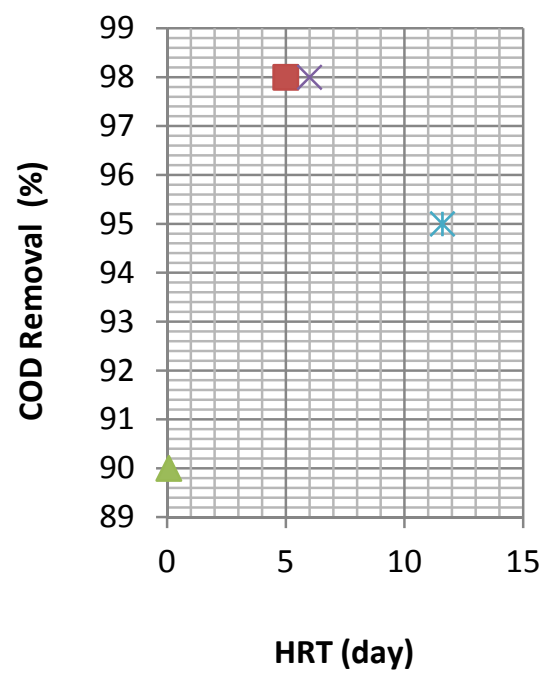

(a)

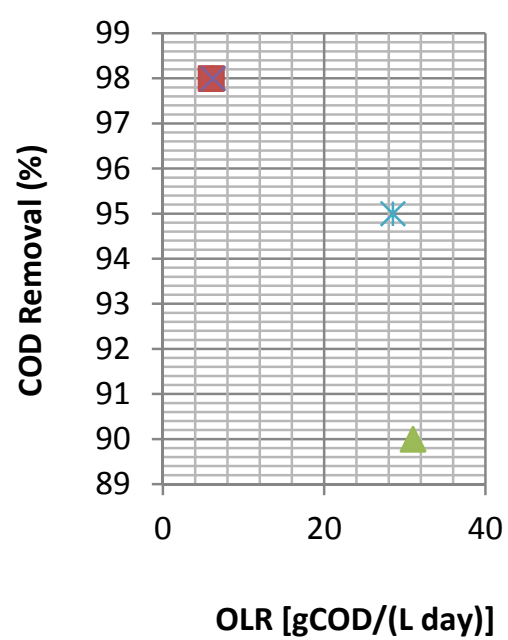

(b)

In addition to AF, FFR and UASB reactors, hybrid and ASB reactors are also used for dairy wastewater treatment. The UASFF reactor is a hybrid reactor which is a combination of a UASB reactor and a UFFR and was developed in order to shorten the startup period. This reactor was used for the rapid biological conversion of organic matter of $\mathrm{CW}$ to biogas. At HRT $48 \mathrm{~h}$ and temperature $36{ }^{\circ} \mathrm{C}$, the COD removal rate of $97.5 \%$ with a short startup time was observed. The highest biogas production rate of $3.75 \mathrm{~L} / \mathrm{d}$ appeared at $\mathrm{HRT}$ of $36 \mathrm{~h}$ [40]. COD removal rate ranged from $90 \%$ to $97 \%$, at an OLR 0.82 to $6.11 \mathrm{~kg} \mathrm{COD} /\left(\mathrm{m}^{3}\right.$ day $)$ and at an HRT 4.1 to 1.7 days has been obtained using mesophilic laboratory scale HAR (combining UASB and fixed bed design) [86], for CW treatment with an influent substrate COD concentration of $10 \mathrm{~g} \mathrm{COD} / \mathrm{L}$. The methane yield was $0.354 \mathrm{~m}^{3} \mathrm{CH}_{4} / \mathrm{kg}$ $\mathrm{COD}_{\text {removed }}$ at an HRT of 1.7 days. The anaerobic treatment of high strength acidic $\mathrm{CW}$ using a laboratory scale UHR [90] had as a result COD removal higher than 95\%, at HRT of 2 days and at 
OLR of about $11 \mathrm{~kg} \mathrm{COD} /\left(\mathrm{m}^{3}\right.$ day). McHugh et al. [84], used two laboratory scale reactors, R1 and R2 to treat low $\left(1 \mathrm{~kg} \mathrm{COD} / \mathrm{m}^{3}\right)$ and high strength $\left(10 \mathrm{~kg} \mathrm{COD} / \mathrm{m}^{3}\right)$ whey wastewaters, respectively, under psychrophilic conditions $\left(<20^{\circ} \mathrm{C}\right)$ and succeeded in high COD removal efficiency. The COD removal efficiencies of the $\mathrm{R} 1$ reactor varied between $70 \%$ and $80 \%$, at OLR $0.5-1.3 \mathrm{~kg} \mathrm{COD} /\left(\mathrm{m}^{3}\right.$ day), and temperature between 20 and $12{ }^{\circ} \mathrm{C}$. The COD removal efficiency of R2 was higher than $90 \%$, at OLR up to $13.3 \mathrm{~kg} \mathrm{COD} /\left(\mathrm{m}^{3}\right.$ day), between 20 and $14{ }^{\circ} \mathrm{C}$. The decline in performance and granule disintegration was reversed by decreasing the OLR of $\mathrm{R} 2$ to $6.6 \mathrm{~kg} \mathrm{COD} /\left(\mathrm{m}^{3}\right.$ day). In the $\mathrm{R} 2$ reactor the biogas volumes generated throughout the study were about 20-25 L/day with biogas methane content between $55 \%$ and $65 \%$ while in the $\mathrm{R} 1$ reactor the biogas methane content remained between $63 \%$ and $77 \%$. In Figure 5, the achievable COD removal rate versus HRT and OLR for each reported study on hybrid reactors, is illustrated.

It should be mentioned that all the works on hybrid reactors for CW treatment achieved high COD removal rates. However, a slightly better COD removal obtained by Najafpour et al. [40], at a short HRT of 2 days similar to that of Calli and Yukselen [90], but with almost double influent COD concentration and OLR, at $35^{\circ} \mathrm{C}$. High COD removal rate also achieved by McHugh et al. [84], by high organic load influent treatment, at $20^{\circ} \mathrm{C}$, proving that satisfactory removal COD can be achieved at low temperatures.

Figure 5. Maximum COD removal versus (a) HRT (days) and (b) OLR [g COD/(L day)] using hybrid reactors for $\mathrm{CW}$ treatment.

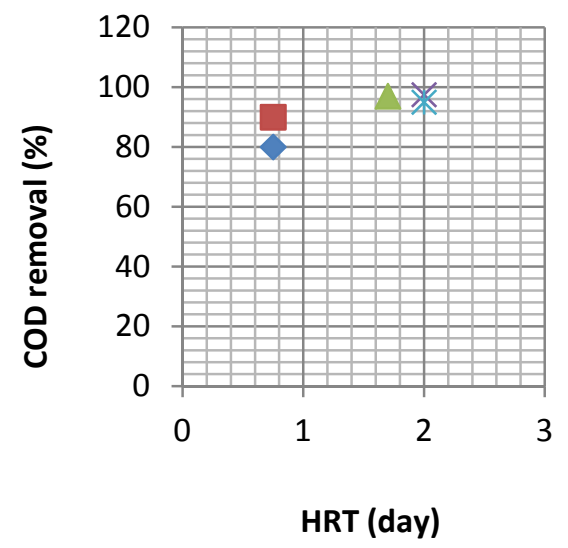

(a)

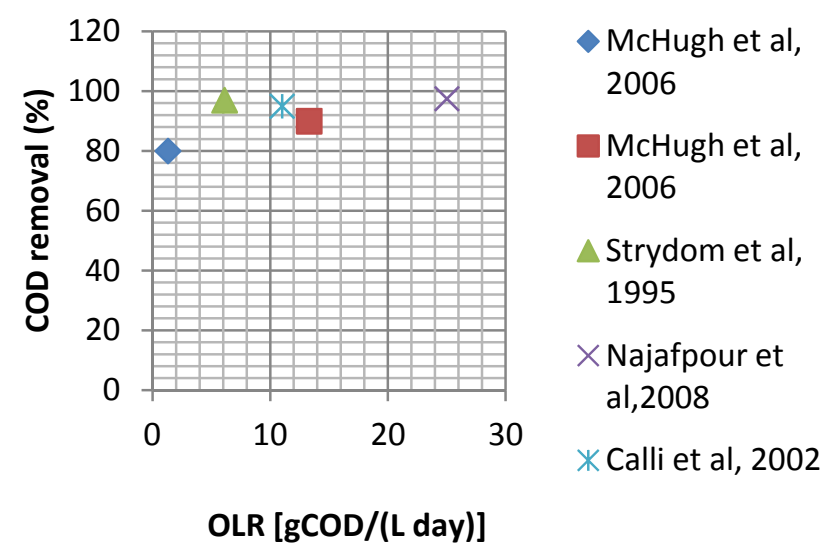

(b)

ASBR has also been studied for $\mathrm{CW}$ treatment and the results have been promising, showing the real potential of this system as an alternative to continuous flow [116,123]. Moreover, ASBR with mechanical stirring proved to be stable and efficient in removing organic matter at influent concentrations varied from 0.6 to $4.8 \mathrm{mg} \mathrm{COD} /(\mathrm{L}$ day). The COD removal rate for filtered samples was always up to $90 \%$. The results were obtained with optimized alkalinity supplementation [91]. Damasceno et al. [124] assessed the behavior of a ASBBR containing immobilized on polyurethane foam for diluted CW treatment when submitted to different OLR [2, 4, 8 and $12 \mathrm{~g} \mathrm{COD/(L} \mathrm{day)]} \mathrm{and}$ feeding strategies (fill time of $10 \mathrm{~min}, 2 \mathrm{~h}$ and $4 \mathrm{~h}$ by a cycle time of $8 \mathrm{~h}$ ). It was concluded that the concentration of total volatile acids varies with the time of filling. For the higher fill times, the highest 
concentrations were observed at the end of the cycle. Furthermore, no significant differences were detected in the maximum concentration of total volatile fatty acids for any of the conditions investigated.

Beyond the reactors mentioned up to this point, there are and some other alternative types of reactors. In a cheese factory in Canada, a novel multi plate reactor has been tried for CW wastewaters. The influent COD ranged between 20 and $37 \mathrm{~kg} / \mathrm{m}^{3}$ and the OLR between 9 and $15 \mathrm{~kg} \mathrm{COD} /\left(\mathrm{m}^{3}\right.$ day). The maximum COD removal was quite high, $92 \%$ and the average methane production rate was $4 \mathrm{~m}^{3} / \mathrm{m}^{3}$ day. Activity level of the biomass maintained or increased during the research. The innovative design of the reactor seemed to be promising for $\mathrm{CW}$ treatment and functioned effectively for one year [101].

Recently, the use of UAPBR to treat CW proved to be a great strategy to achieve high COD removal efficiency in a short time. COD and lactose removals rose to $94.5 \%$ and $99 \%$ correspondingly, at HRT of $16 \mathrm{~h}$ and room temperature $\left(25^{\circ} \mathrm{C}\right)$. The highest methane yield was achieved at $16 \mathrm{~h}$ of HRT and the highest volumetric rate of biogas production was achieved at HRT of $6 \mathrm{~h}$ [104].

ARBCR was used to anaerobically treat salty $\mathrm{CW}$. The optimum performance was achieved at an HRT of 3 days and at $37{ }^{\circ} \mathrm{C}$ and the resulting COD removal was $85 \%$. The methane content in the biogas was close to $74 \%$ [87]. A similar COD reduction of $83 \%$ was achieved, using a MAB for the anaerobic treatment of salty whey diluted with dairy effluents, at an HRT of 2 days and at $37{ }^{\circ} \mathrm{C}$. The methane content in the produced biogas was 68\% [88]. Figure 6, illustrates the COD removal rate, versus $\mathrm{HRT}$ (days) and OLR [g COD/(L day)], reported on certain alternative types of reactors.

Figure 6. Maximum COD removal versus (a) HRT (days) and (b) OLR [g COD/(L day)] using alternative types of reactors for $\mathrm{CW}$ treatment.

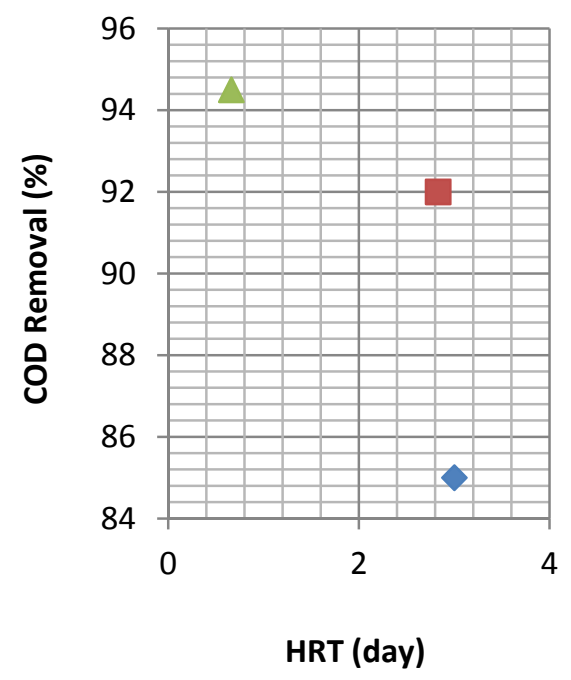

(a)

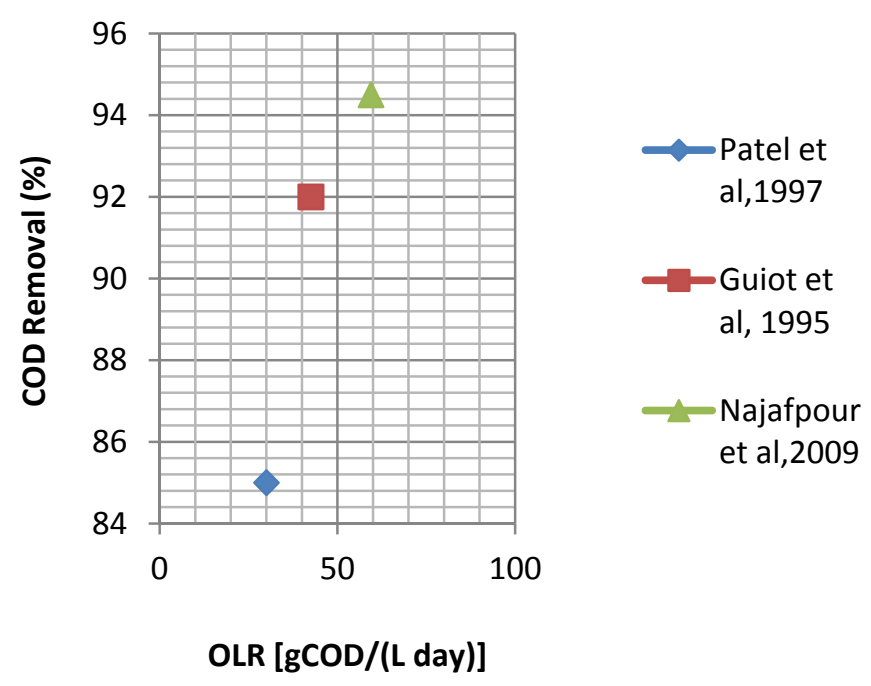

(b)

From Figure 6 it is noticed that Najafpour et al. [104] achieved the highest COD removal rate at lower HRT and the highest OLR compared with the other two studies. It is also remarkable that this study was carried out at low temperature of $25^{\circ} \mathrm{C}$, while the other works carried out at mesophilic conditions $\left(34-37^{\circ} \mathrm{C}\right)$.

In the conventional single reactor systems, as reported up to this point, there is a sensitive balance between the acid-forming and methane-forming microorganisms which are kept together, since both 
groups differ significantly in terms of physiology, nutritional needs, growth kinetics and sensitivity to environmental conditions. The problems of stability and control in conventional design applications have led researchers to seek new solutions [21].

\subsection{Two Phase (Two Stage) Anaerobic Treatment of Cheese Whey}

The idea of development of $\mathrm{AD}$ as a two-step procedure came from the aspect that the process of the AD consists of two groups of different sets of activities [34]. Pohland and Ghosh [125] were the first to suggest the physical separation of the two groups of microorganisms, acid and methane formers, in two separate reactors. Optimum environmental conditions for each group of microorganisms should be provided in the reactors in order to enhance the overall process stability and control. The performance of acidogenic reactor (acid phase) is particularly crucial for the two phase anaerobic effluent stabilization, since the acidogenic reactor should provide suitable substrate for the subsequent methanogenic reactor (methane phase) [126]. Hall [127] has summarized the advantages and disadvantages of one and two phase anaerobic treatment.

In order to investigate the two stage $\mathrm{AD}$ of $\mathrm{CW}$, various combinations of reactors have been used. UASB reactors were used as acidogenic and methanogenic reactors [128], or CSTR and UAF were used for acidogenesis and methanogenesis, respectively [99]. With the latter combination system, in the upflow methanogenic filter, 95\% COD removal was attained at $35{ }^{\circ} \mathrm{C}$ and HRT 4 days, with biogas production rate of $0.55 \mathrm{~m}^{3} / \mathrm{kg} \mathrm{COD}$ removed. Similar COD removal (93\%) at an HRT of 5 days was achieved by another combination system using AnRBC reactors, one for each stage [81]. Saddoud et al. [34], studied a system consisting of a stirred acidogenic reator followed by a methanogenic reactor coupled with a membrane filtration system for the removal of soluble effluents and the preservation of solids. The average removals of $\mathrm{COD}, \mathrm{BOD}_{5}$ and TSS were $98.5 \%, 99 \%$ and $100 \%$, respectively, with daily biogas production higher than 10 times reactor volume and biogas methane content higher than $70 \%$. However, the flux declined because of the formation and compaction of a cake layer on the membrane surface caused by the particles accumulated inside the pores of the membrane.

Yang et al. [100], comparing one and two phase thermophilic AD systems for CW treatment concluded that the two phase process was more suitable for the management of $\mathrm{CW}$ wastewaters, with maximum COD removal rate and yield of methane production were $116 \%, 43 \%$ and $6 \%$ higher, respectively, than those of the single phase system. This conclusion also follows from the evaluation of $\mathrm{AD}$ of three different dairy effluents (cheese, fresh milk and powder/butter), using a laboratory scale mesophilic two stage system. For effluents from the cheese factory at an OLR of $2.82 \mathrm{~kg} \mathrm{COD} /\left(\mathrm{m}^{3}\right.$ day), $97 \%$ of COD removal was achieved [93]. Cheese processing effluents were also used to determine the biokinetics of mesophilic acidogens. At $\mathrm{pH} 7$ and temperature $36.2{ }^{\circ} \mathrm{C}$, the maximum microbial growth $\left(\mu_{\max }\right)$, the half saturation coefficient $\left(\mathrm{K}_{\mathrm{s}}\right)$, the maximum microbial growth rate $(\mathrm{Y})$ and the microbial decay rate $\left(\mathrm{K}_{\mathrm{d}}\right)$ were calculated to be 9.9 days $^{-1}, 134 \mathrm{mg}$ COD/1, $0.29 \mathrm{mg}$ MVSS/mg COD and 0.14 days $^{-1}$, correspondingly [2,129].

Ghaly [78], used an UAR in order to investigate the effects of a two stage AD, with and without control of $\mathrm{pH}$ at the methanogenesis stage. The results indicated that by controlling $\mathrm{pH}$ (alkali addition) of the methanogenic stage, a significant increase in the biogas production rate and methane yield as well as a decrease in COD and solids concentrations of the CW, have been achieved. For instance, at 
an HRT of 20 days and at $35{ }^{\circ} \mathrm{C}$, with $\mathrm{pH}$ control the COD removal rose to $36 \%$, while without $\mathrm{pH}$ control it was much lower (15.6\%). However, Garcia et al. [95], suggested that recirculation of reactor effluent of the methanogenesis reactor produces a dilution of the influent which allows a good system stability, without the necessity of adding alkalinity for $\mathrm{pH}$ control. At an OLR of $30 \mathrm{~kg} \mathrm{COD} /\left(\mathrm{m}^{3}\right.$ day) and at an HRT of 0.45 days in the acidification reactor and at an OLR $15 \mathrm{~kg} \mathrm{COD} /\left(\mathrm{m}^{3}\right.$ day) and at HRT 0.75 days in the metanogenesis reactor, higher than 99\% COD removal was obtained. One way to improve the performance efficiency of digesters for high content wastewaters treatment, especially the high rate anaerobic systems, such as UASB reactors or UAF, is to promote an adequate pretreatment of the substrate. Gannoun et al. [4], used a combined system with ecological pretreatment before the AD.

The pretreatment step was based on the L. paracasei growth on $\mathrm{CW}$, the fermentation of lactose into lactic acid and the precipitation of organic material after lime addition. With ecological pretreatment of $\mathrm{CW}$ the startup has been after four weeks without any significant problem. Furthermore, the contained pollution was decreased and the BOD/COD ratio was improved from 0.5 to 0.7 , making the $\mathrm{CW}$ wastewaters more suitable for anaerobic treatment. CSTR with variable working volume was used to supply UAF with the biologically pretreated CW. The stable operation of the UAF is mainly due to the liberation of ammonia from the degradation of the residual proteins in the pretreated $\mathrm{CW}$ and the synergistic interaction between the acidogenic and methanogenic bacteria. With this combined system the highest COD removal of $98 \%$ was achieved at HRT varying from 2 to 5 days, OLR $4 \mathrm{~g} \mathrm{COD/(L} \mathrm{day)} \mathrm{and} \mathrm{at} \mathrm{stable} \mathrm{operating} \mathrm{conditions} \mathrm{throughout} \mathrm{the} \mathrm{experiment} \mathrm{[4].} \mathrm{Figure} \mathrm{7,}$ illustrates the percentage of COD removal versus HRT and OLR for two phase AD systems which have been reported up to this point.

Figure 7. Maximum COD removal versus (a) HRT (days) and (b) OLR [g COD/(L day)] with the use of two phase anaerobic digestion system for $\mathrm{CW}$ wastewaters treatment.

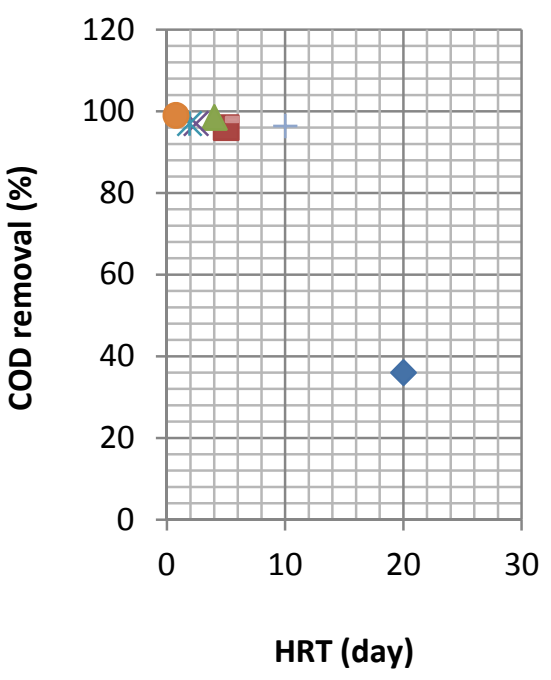

(a)

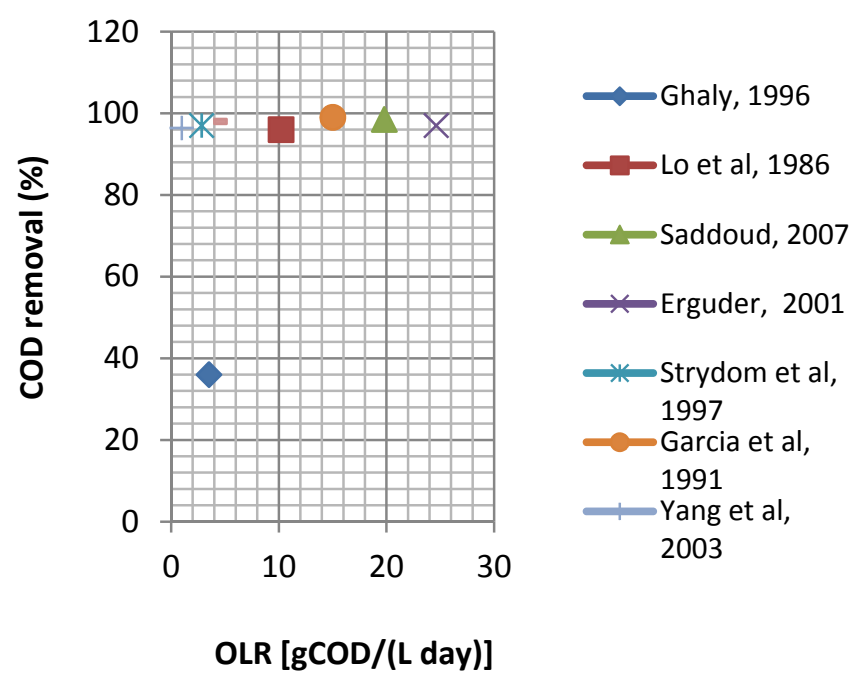

(b)

From Figure 7, it is observed that COD removal rate does not vary significantly from one study to another regardless of HRT and OLR. This proves, as already mentioned, that the two phase AD system is an effective solution for CW treatment, attaining high COD removal rates in a short HRT. Garcia et al. [95], succeeded in achieving the highest COD removal rate at the lowest HRT and 
relatively low influent organic loading. However, the value of OLR is relatively modest compared with the other studies. Saddoud et al. [34], obtained the next highest COD removal rate (98.5\%) with the highest influent COD. It is also noteworthy the high COD removal rate was achieved by Gannoun et al. [4], with ecologic pretreatment reducing the wastewaters pollution content before entering the reactor for AD. The pretreated $\mathrm{CW}$ which used as substrate in $\mathrm{AD}$ by UAF has quite lower organic loading (influent COD) and OLR compared to others [10,34,81].

\subsection{Anaerobic/Aerobic Reactors}

Two steps are usually required for complete treatment of $\mathrm{CW}$ wastewaters. The anaerobic degradation of the main fraction of organic matter and then the aerobic treatment of the partially treated wastewaters, in order to reduce the final organic load of the effluent and to fulfill the discharge requirements [83]. The aerobic treatment step can be provided by aerated ponds $[98,117]$, or aerobic jet loop membrane reactors [3].

Malaspina et al. [70], reported that during an anaerobic-aerobic biological process, 98\% COD reduction was achieved at an OLR of $10 \mathrm{~g} \mathrm{COD} /(\mathrm{L}$ day) in the anaerobic DUHR. Post treatment was subsequently performed with the use of SBR resulting in higher than $90 \%$ of COD and nutrients removal rates. The main objective was to reduce the high concentration of nitrogen and phosphorus still remaining in the anaerobic treated CW. The nitrogen and phosphorus removals were $66 \%-93 \%$ and $35 \%-93 \%$, respectively.

Full-scale anaerobic/aerobic cheese wastewaters treatment by a system containing a grease trap, UASB type pond, aerated pond, effluent polishing pond, achieved reduction rates in $\mathrm{BOD}_{5}, \mathrm{COD}$, TSS, oil and grease, $98 \%, 96 \%, 98 \%$ and $99.8 \%$, respectively [98].

Regarding the temperature of digestion, most research on CW wastewater treatments, have been conducted under mesophilic and thermophilic conditions, although psychrophilic digestion can lead to lower cost treatment and can be a more suitable option for small scale cheese producers [84]. A preliminary study on sequential anaerobic and aerobic treatment of CW wastewaters, at psychrophilic temperatures in a single digester SBR of $0.5 \mathrm{~L}$ volume, was carried out by Frigon et al. [130]. The SBR operated at cycles of $48 \mathrm{~h}$, with different levels of aeration after the initial incubation of $30 \mathrm{~h}$. By adding $54 \mathrm{mg} \mathrm{O}_{2} / \mathrm{g} \mathrm{COD}_{\text {influent }}$ over $16 \mathrm{~h}$ achieved the best performance of the system, with soluble COD removal of $99 \%$ and a residual soluble COD of $104 \pm 22 \mathrm{mg} / \mathrm{L}$. Recently, the same research group [83], in order to reduce the cost of the investment, evaluated in a single digester the potential of psychrophilic $\mathrm{AD}$, for the most of the biodegradable materials, followed by aerobic polishing sequence. The concept of coupling anaerobic and aerobic steps inside one digester is promising. The total cycle time $\left(\mathrm{T}_{\mathrm{c}}\right)$ must be longer than 2 days for the efficient biodegradable fraction of $\mathrm{CW}$ removal, at $21{ }^{\circ} \mathrm{C}$. Moreover, the sequential anaerobic and aerobic degradation of the $\mathrm{CW}$ wastewaters can be enhanced by improving the compartmentalization of the anaerobic and aerobic biomass inside the reactor. The integrated anaerobic and aerobic degradation in a single reactor is able to improve the overall degradation efficiency. In Figure 8 the reported COD removal rates obtained by anaerobic/aerobic digestion, versus HRT (days) and OLR [g COD/(L day)], are shown.

It is observed that Frigon et al. [83] achieved the highest COD removal at the shortest HRT and at psychrophilic conditions $\left(20^{\circ} \mathrm{C}\right)$, in a single digester of anaerobic and aerobic treatment. Therefore the 
use of integrated reactors (anaerobic/aerobic digestion) with stacked configuration in treating high strength industrial wastewaters is advantageous in terms of minimal space requirements, low capital cost and COD removal efficiencies obtained. However, most integrated reactors reported and described by Chan et al. [131] have not been applied on a large industrial scale and further research is required in order to evaluate the performance of these promising reactors on a larger scale.

Figure 8. The highest COD removal versus (a) HRT (days) and (b) OLR [g COD/(L day)] using two steps anaerobic/aerobic digestion system for CW treatment.

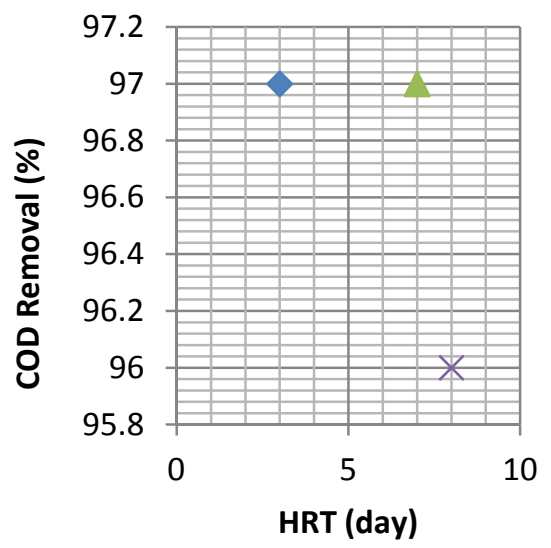

(a)

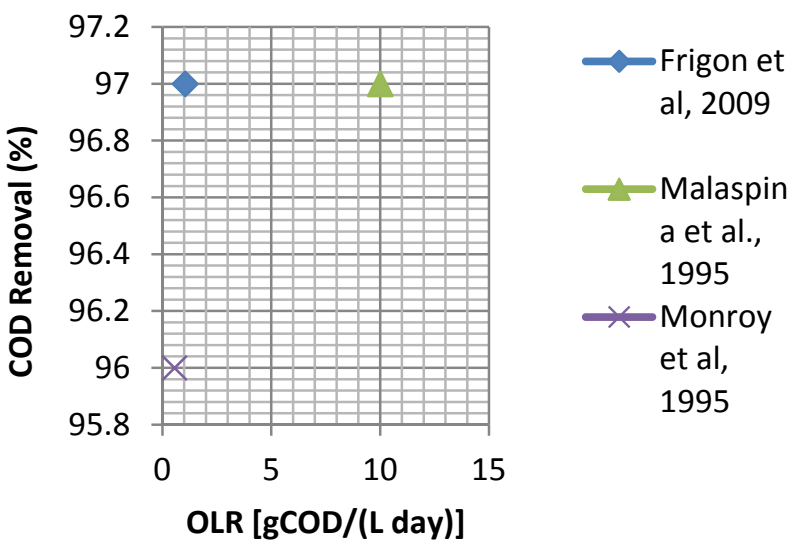

(b)

\subsection{Dairy Industries Using Anaerobic Digestion Systems}

As already mentioned, although many studies have been carried out on a laboratory or pilot scale, the known industrial scale applications of AD are limited. A number of factories producing cheese and dairy products that have implemented AD systems in order to reduce the effluents pollution load and to produce biogas covering part of their energy needs, are presented below.

Valbio Canada Inc. [132], is one of the known companies installing AD systems. One of its projects is the AD system with UASB reactor installed in Tyras SA dairy industry (in service since 2009) which is located in Trikala, Greece. The system efficiency after three weeks of operation rose to $93 \%$. The influent COD concentration is $55,000 \mathrm{mg} / \mathrm{L}$, while after CW AD treatment, the effluent COD concentration is $1100 \mathrm{mg} / \mathrm{L}$. It has been estimated that with the biogas produced, the company covers about $75 \%$ of its energy needs. Blackburn Cheese Dairy, in Jonquieres, Quebec, Canada, treats anaerobically 0.7 million L/year using a Valbio Methacore fluidized bed reactor of $30 \mathrm{~m}^{3}$ (Figure 9) since 2007.

Post treatment of treated $\mathrm{CW}$ follows the $\mathrm{AD}$, including aerobic, nitrogen and phosphorous treatments. Through this process $28,000 \mathrm{~m}^{3} /$ year biogas $(170,000 \mathrm{kWh} /$ year or $580 \mathrm{Btu} /$ year) are produced covering factory's energy needs, while at the same time $98 \%$ and $99 \%$ COD and BOD removal respectively, are achieved. A similar system is operated since January 2010 at Port Joli Cheese Dairy in Quebec (Canada), which treats 0.35 million L/year of cheese whey and 0.63 million L/year wash waters. The total COD of effluents is $27,000 \mathrm{~kg}$ /year. A sequential biological reactor for nitrogen and phosphorus treatment follows the anaerobic fluidized bed reactor of $16 \mathrm{~m}^{3}$ volume. The system produces $91,000 \mathrm{kWh} /$ year (310 MBtu/year) biogas, achieving 95\% of COD and BOD removal. At La Vachea 
Maillotte Cheese Dairy (La Sarre, Quebec, Canada) a similar system, established since June 2010, treats 2.5 million L/year of CW with total COD 175,000 kg/year. The produced biogas is $94,000 \mathrm{~m}^{3}$ (640,000 $\mathrm{kWh} /$ year), with the COD and BOD removal being $91 \%$ and $94 \%$, respectively.

Figure 9. Valbio's Methacore anaerobic digestion system (fluidized bed) with anaerobic granular sludge used in different units of effluent treatment [132].

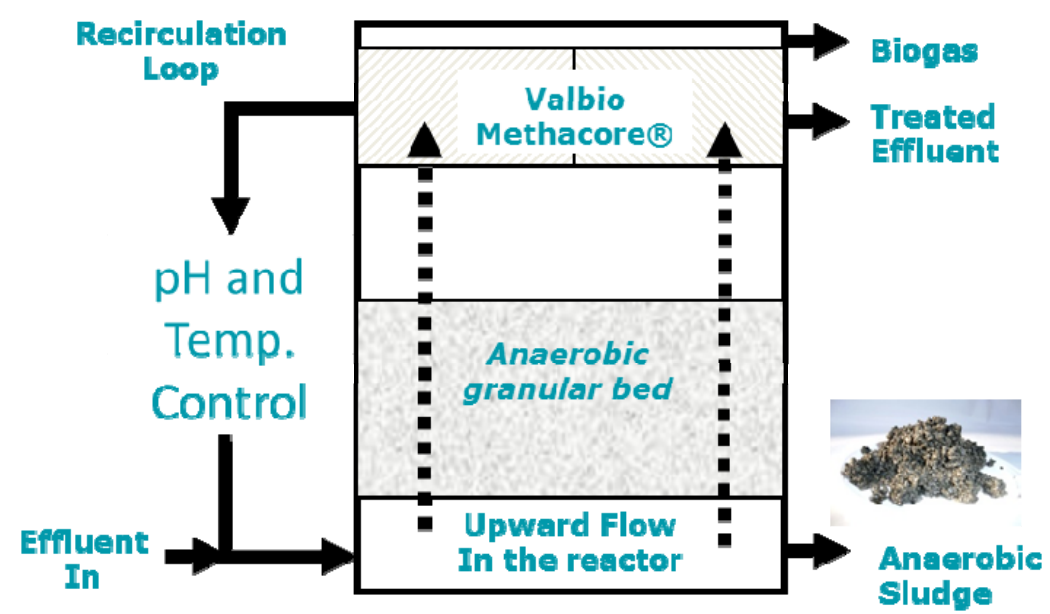

The same COD and BOD removal rates are achieved by anaerobic treatment of wastewaters with total COD of $127,000 \mathrm{~kg}$ /year (4.9 million liters washwaters per year and 1.6 million liters whey per year) in Charlevoix Dairy (Baies St Paul, Quebec, Canada). The treatment system has been in service since March 2011. The system consists of a fluidized bed reactor of $56 \mathrm{~m}^{3}$ and is followed by aerobic post treatment and eco machine (phyto) with nitrogen and phosphorus treatment. The produced biogas is $67,600 \mathrm{~m}^{3} /$ year (equivalent $460,000 \mathrm{kWh} /$ year or 1,650 MBtu/year).

Naskeo Environment [133], is another company dealing with the installation of AD systems. One of its projects is the installation of valorization of the soluble industrial effluents (white water and whey) of the cheese dairy of the Pays de Maroilles (North of France) using Proveo AD (Figure 10) and aerobic completion SBR systems. The average thermal power during the process is estimated $45 \mathrm{~kW}$ corresponding to approximately $175 \mathrm{~m}^{3} /$ day biogas production and the average effluent purifying output is approximately $99 \%$.

Figure 10. High efficiency anaerobic digestion for effluents_-Proveo [133].

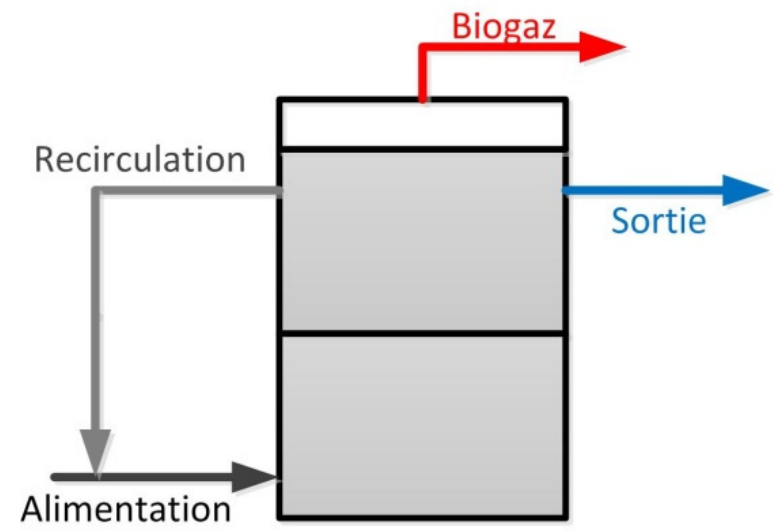


An anaerobic treatment unit has also been installed by Esi.info Company [134], at Landfrisch Molkerei in Austria. This project involved the treatment of whey and wastewater from cottage cheese production using anaerobic treatment in a Mixed Sludge Bed reactor which is designed to treat $180 \mathrm{~m}^{3}$ whey/day and 11,000 kg COD/day with COD removal efficiency higher than $90 \%$ and electrical and thermal energy production of 12 and $13 \mathrm{MWh} / \mathrm{d}$, respectively.

Monchevre (located in Belmont, WI), is the first goat cheese manufacturer in United States to use this type of wastewater treatment. The AD system installed by Procorp Enterprises LLC [135], and has been in service since October 2010. The result of the process is $5,270 \mathrm{KWh}$ of energy production daily that can power 200-240 local homes.

In the literature there are many economic analyses on $\mathrm{AD}$ systems for various wastewater treatments which have proved that this process is an economically viable method for wastewater treatment although it demands high investments. The total capital costs of anaerobic digester plants may range from a few hundred thousand to a few million euros. Typically, the capital and running costs of a biogas electricity generating plant are $\$ 3,700$ to $\$ 7,000 / \mathrm{kWh}$ and $\$ 0.02 / \mathrm{kWh}$, respectively [136]. Financing is therefore one of the key elements in order to ensure project viability. The financing scheme of a biogas plant project differs from country to country, but in general, low interest long term loans are used. Some of the feasibility studies concluded that the payback period ranges from 5 to 16 years, when operated under optimum and worst conditions, respectively. Government financial incentives for producing green energy can reduce the payback period significantly [137].

Regarding the economic analysis of CW treatment there is a lack of related information in the available literature. An indicative example is the economic analysis work of Spachos and Stamatis [67], which is performed using the Net Present Value (NPV) method. The Total Capital Investment of the system which produces $272.2 \mathrm{~kg} / \mathrm{hr}$ of biogas calculated to be $2,069,000 €$. The company has a loan of investment money from a bank with an interest rate of $7 \%$ and a repayment period of 10 years. The incoming cash flow comes from the savings in natural gas and the outgoing cash flows resulting from the operational and maintenance costs and the installments paid for a period of ten years. Hence, given the steam produced from the biogas, the natural gas which would be used instead is calculated to almost $157 \mathrm{~m}^{3} / \mathrm{hr}$, and taking into account that the mean cost of natural gas for 2009 was $0.31879 € / \mathrm{m}^{3}$, the saving for the first year amounts to $347,587 €$. Furthermore, it has been estimated that with the biogas produced, the company covers about $75 \%$ of its energy needs. The result of the economic analysis reveals that the anaerobic treatment of whey is a profitable and sustainable investment for the company.

However, the scale is a significant factor when evaluating the economic feasibility of AD systems. An ongoing project on a small Minnesota farm is testing parameters. There is a general consensus that projects on small scale are not going to be economically feasible until there are higher net metering rates (for more details see [138]).

\section{Conclusions}

Cheese whey is increasingly being recognized as an important resource to produce value added products and "clean" energy, rather than as a waste stream with a high pollution load. The bioactive proteins whey gradually find application not only in food products, but also in cosmetics and in the pharmaceutical field. After recovery of proteins and other nutrients, a stream rich in lactose remains, 
imposing a major environmental problem that imperatively requires further treatment. Lactose is used as a component in foods and as filler or coating agent for tablets (pills) in the pharmaceutical industry. However, its use in food products is limited because of low digestibility and poor solubility (ability to crystallize). In addition, lactose is used as chemical feedstock for the production of lactose products (for example lactulose, lactitol, lactobionic acid, etc.) and as substrate for production of valuable compounds by fermentation (ethanol, biogas, hydrogen etc.).

Regarding the production of biogas from $\mathrm{CW}$ effluents $\mathrm{AD}$ is an effective method, because of its advantages compared with other methods (process simplicity, high energy efficiency, low cost). Simultaneously with the biogas production, a high removal rate of pollution load expressed by removing $\mathrm{COD}$ and $\mathrm{BOD}_{5}$ is achieved using various types of reactors, from simple to more complex (anaerobic filters, fixed film reactors, UASB, hydrid reactors, etc.). The UASB reactors are the most common reactor configuration employed for $\mathrm{CW}$ wastewater treatment, mainly because of their ability to treat large volumes of effluents in a relatively short period of time.

In conventional single (one phase) reactors, the acid forming and methane forming microorganisms are kept together and lead to instability and control problems. Moreover, high concentration of suspended solids in the $\mathrm{CW}$ can also affect adversely the performance of the conventional anaerobic treatment processes, especially the most commonly used UAF. With the two stage AD processes, these problems can be overcome and therefore this system should be considered as a better treatment system for $\mathrm{CW}$ wastewater. However, the full-scale two-phase applications for dairy effluents in literature are scarce. In this type of anaerobic system the kinetic and microbiological aspects of the acidogenic reactors operating with preferably different complex type substrates should also be evaluated in more detail with focus on adverse effects that organic substrates might cause. Additionally the subsequent methane reactor should be another substantial area for further investigation.

Nevertheless, with the $\mathrm{AD}$ process a percentage of pollution load remains in the treated effluent resulting in the necessity of subsequent processing. Anaerobic/aerobic digestion is a complete system for wastewater treatment. Additionally, the use of integrated reactors (anaerobic/aerobic digestion) with stacked configuration has been proved advantageous in treating $\mathrm{CW}$ wastewater because of minimal space requirements, low capital cost and excellent COD removal efficiencies and is a promising treatment method. Further work is required to evaluate the performance of these promising reactors on a larger scale including the biogas capture system and utilization of the suspended carrier or packing medium.

Another important factor in the AD is the start-up phase which is considered the most critical step in the operation of anaerobic digesters. High microbial loading inoculum material needs to be added in the mixture of biomass when start-up the anaerobic digester. So far, only a few reports can be found about the inoculums and their proportion used on AD of CW. Similarly, there is luck of information on the detailed composition of the $\mathrm{AD}$ effluent which is very important for either direct discharge or the following treatment (anaerobic or aerobic digestion). Both of these matters should be taken into account in the future research.

In order to evaluate the state of technology concerning the COD removal rate ability for different type of reactors and systems in use, an effort to establish a common comparative basis has been made. It was observed that most studies dealing with $\mathrm{AD}$ of $\mathrm{CW}$ show no significant differences in the $\mathrm{COD}$ removal rate. The differences being mainly on HRT, OLR and influent organic loading, in which these 
COD removal rates were achieved. Generally, it is quite difficult to compare the systems operating in different laboratories due to differences in the anaerobic sludge characteristics and the operating parameters (temperature of reactor's operation, HRT, OLR and others) used. Therefore it would be useful for the future research efforts to attempt referencing where possible to similar operating conditions in order to get a clearer and more complete picture of the AD systems technology on a comparative basis.

In the available literature, the number of industrial scale existing operating AD systems, especially in cheese industries, is limited and mainly concern conventional reactors. However, the increasingly stringent regulations for the wastewater disposal and the need to cover energy requirements necessitate the continuous improvement of technology and study of the operation of more complex and optimized two stage systems, anaerobic/aerobic digestion reactors at full industrial scale to be applied in the near future. Moreover, it is understood that the interest has shifted to the nitrogen and phosphorus removal from dairy waste due to more strict environmental regulations and therefore current research efforts clearly seem to focus on this particular topic.

Analysis and optimization of complete industrial scale AD systems of CW (from biogas production to its combustion) is essential. More research is required to increase the operation efficiency of a complete system on industrial scale (choice and dimensioning o equipment such as micro turbines, fuel cells, exchangers, etc.).

In conclusion, since $\mathrm{CW}$ is a major pollutant, but simultaneously an important energy source, utilization for clean energy (biogas, methane and hydrogen) production is of paramount importance. Therefore, further research in the field of exploitation and management of $\mathrm{CW}$, together with the development of new technologies for its treatment, are necessary. To this end, the development of technologies for hydrogen production from $\mathrm{CW}$ wastewater, particularly by acidogenesis is currently worth investigating. The dark $\mathrm{AD}$ processing for $\mathrm{CW}$ treatment has been proved a suitable method for direct $\mathrm{H}_{2}$ production on lab-scale. Further research is required to evaluate the performance of this process on a larger scale. Also, the direct use of $\mathrm{CW}$ in fuel cells for production of electricity seems to be a promising option.

\section{Acknowledgments}

The authors wish to express their gratitude to the financial support by the Research Fund of the University of Thessaly through grant 15985/9.11.11.

\section{References}

1. Papachristou, E.; Lafazanis, C. Application of membrane technology in the pretreatment of cheese dairies wastes and co-treatment in a municipal conventional biological unit. Water Sci. Technol. 1997, 32, 361-367.

2. Demirel, B.; Yenigun, O.; Onay, T.T. Anaerobic treatment of dairy wastewaters: A review. Process Biochem. 2005, 40, 2583-2595.

3. Farizoglu, B.; Keskinler, B.; Yildiz, E.; Nuhoglu, A. Cheese whey treatment performance of an aerobic jet loop membrane bioreactor. Process Biochem. 2004, 39, 2283-2291. 
4. Gannoun, H.; Khelifi, E.; Bouallagui, H.; Touhami, Y.; Hamdi, M. Ecological clarification of cheese whey prior to anaerobic digestion in upflow anaerobic filter. Bioresour. Technol. 2008, 99, 6105-6111.

5. Omil, F.; Garrido, J.M.; Arrojo, B.; Méndez, R. Anaerobic filter reactor performance for the treatment of complex dairy wastewater at industrial scale. Water Res. 2003, 37, 4099-4108.

6. Wust, E.L. Single-Phase and Two-Phase Cheese Wastewater Treatment by Anaerobic SBRs. Ph.D. Disseration, Marquette University, Milwaukee, WI, USA, 2003.

7. Orhon, D.; Görgün, E.; Germirli, F.; Artan, N. Biological treatability of dairy wastewaters. Water Res. 1993, 27, 625-633.

8. Vidal, G.; Carvalho, A.; Méndez, R.; Lema, J.M. Influence of the content in fats and proteins on the anaerobic biodegradability of dairy wastewaters. Bioresour. Technol. 2000, 74, 231-239.

9. Gavala, H.N.; Kopsinis, H.; Skiadas, I.V.; Stamatelatou, K.; Lyberatos, G. Treatment of dairy wastewater using an upflow anaerobic sludge blanket reactor. J. Agr. Eng. Res. 1999, 73, 59-63.

10. Ergüder, T.H.; Tezel, U.; Güven, E.; Demirer, G.N. Anaerobic biotransformation and methane generation potential of cheese whey in batch and UASB reactors. Waste Manag. 2001, 21, 643-650.

11. Switzenbaum, M.S.; Danskin, S.C. Anaerobic expanded bed treatment of whey. Agric. Wastes 1982, 4, 411-426.

12. Marshall, K.R.; Harper, W.J. The treatment of wastes from the dairy industry. In Surveys in Industrial Wastewater Treatment—Food and Allied Industries; Barnes, D., Forster, S.T., Hurdley, S.E., Eds.; Pitman Publishing: London, UK, 1984; Volume 1, pp. 296-376.

13. Mawson, A.J. Bioconversions for whey utilization and waste abatement. Bioresour. Technol. 1994, 47, 195-203.

14. Sienkiewicz, T.; Riedel, C.L. Whey and Whey Utilization: Possibilities for Utilization in Agriculture and Foodstuffs Production, 2nd ed.; Th. Mann Gelsenkirchen-Buer: Berlin, Germany, 1990.

15. Siso, M.I.G. The biotechnological utilization of cheese whey: A review. Bioresour. Technol. 1996, 57, 1-11.

16. Durham, R.J.; Hourigan, J.A. Waste management and co-product recovery in dairy processing. In Handbook of Waste Management and Co-Product Recovery in Food Processing; Waldron, K., Ed.; Woodhead Publishing: Cambridge, UK, 2007.

17. Smithers, G.W. Whey and whey proteins -From "gutter-to-gold". Int. Dairy J. 2008, 18, 695-704.

18. Audic, J.L.; Chaufer, B.; Daufin, G. Non-food applications of milk components and dairy co-products: A review. Lait 2003, 83, 417-438.

19. Rajeshwari, K.V.; Balakrishnan, M.; Kansal, A.; Lata, K.; Kishore, V.V.N. State-of-the-art of anaerobic digestion technology for industrial wastewater treatment. Renew. Sustain. Energy Rev. 2000, 4, 135-156.

20. Saleh, M.M.A.; Mahmood, U.F. Anaerobic digestion technology for industrial wastewater treatment. In Proceedings of Eighth International Water Technology Conference (IWTC8), Alexandria, Egypt, 27 March 2004.

21. Demirel, B.; Yenigün, O. Two-phase anaerobic digestion processes: A review. J. Chem. Technol. Biotechnol. 2002, 77, 743-755.

22. Ke, S.; Shi, Z.; Fang, H.H.P. Applications of two-phase anaerobic degradation in industrial wastewater treatment. Int. J. Environ. Pollut. 2005, 23, 65-80. 
23. Chen, Y.; Cheng, J.J.; Creamer, K.S. Inhibition of anaerobic digestion process: A review. Bioresour. Technol. 2008, 99, 4044-4064.

24. Ghaly, A.E.; Kamal, M.A. Submerged yeast fermentation of acid cheese whey for protein production and pollution potential reduction. Water Res. 2004, 38, 631-644.

25. Ferchichi, M.; Crabbe, E.; Gil, G.-H.; Hintz, W.; Almadidy, A. Influence of initial pH on hydrogen production from cheese whey. J. Biotechnol. 2005, 120, 402-409.

26. Kisaalita, W.S.; Pinder, K.L.; Lo, K.V. Acidogenic fermentation of lactose. Biotechnol. Bioeng. 1987, 30, 88-95.

27. Zadow, J.G. Utilization of milk components: Whey. In Modern Dairy Technology, Advances in Milk Processing, 2nd ed.; Robinson, R.K., Ed.; Chapman \& Hall: London, UK, 1994; Volume 1.

28. Kavacik, B.; Topaloglu, B. Biogas production from co-digestion of a mixture of cheese whey and dairy manure. Biomass Bioenergy 2010, 34, 1321-1329.

29. Venetsaneas, N.; Antonopoulou, G.; Stamatelatou, K.; Kornaros, M.; Lyberatos, G. Using cheese whey for hydrogen and methane generation in a two-stage continuous process with alternative pH controlling approaches. Bioresour. Technol. 2009, 100, 3713-3717.

30. Panesar, P.S.; Kennedy, J.F.; Gandhi, D.N.; Bunko, K. Bioutilisation of whey for lactic acid production. Food Chem. 2007, 105, 1-14.

31. Bylund, G. Dairy Processing Handbook; Tetra Pak Processing Systems: Lund, Sweden, 1995.

32. Jelen, P. Whey processing. In Encyclopedia of Dairy Sciences; Roginski, H., Fuquay, J.W., Fox, P.F., Eds.; London Academic Press: London, UK, 2003; Volume 4, pp. 2739-2751.

33. Ben-Hassan, R.; Ghaly, A. Continuous propagation of Kluyveromyces fragilis in cheese whey for pollution potential reduction. Appl. Biochem. Biotechnol. 1994, 47, 89-105.

34. Saddoud, A.; Hassaïri, I.; Sayadi, S. Anaerobic membrane reactor with phase separation for the treatment of cheese whey. Bioresour. Technol. 2007, 98, 2102-2108.

35. Kisaalita, W.S.; Lo, K.V.; Pinder, K.L. Influence of whey protein on continuous acidogenic degradation of lactose. Biotechnol. Bioeng. 1990, 36, 642-646.

36. Hwang, S.; Hansen, C.L. Characterization of and bioproduction of short-chain organic acids from mixed dairy-processing wastewater. Trans. ASAE 1998, 41, 795-802.

37. Vasala, A.; Panula J.; Neubauer, P. Efficient lactic acid production from high salt containing dairy by-products by Lactobacillus salivarius ssp. salicinius with pre-treatment by proteolytic microorganisms. J. Biotechnol. 2005, 117, 421-431.

38. Guimarães, P.M.R.; Teixeira, J.A.; Domingues, L. Fermentation of lactose to bio-ethanol by yeasts as part of integrated solutions for the valorisation of cheese whey. Biotechnol. Adv. 2010, $28,375-384$.

39. Gelegenis, J.; Georgakakis, D.; Angelidaki, I.; Mavris, V. Optimization of biogas production by co-digesting whey with diluted poultry manure. Renew. Energy 2007, 32, 2147-2160.

40. Najafpour, G.D.; Hashemiyeh, B.A.; Asadi, M.; Ghasemi, M.B. Biological treatment of dairy wastewater in an upflow anaerobic sludge-fixed film bioreactor. Am. Eurasian J. Agric. Environ. Sci. 2008, 4, 251-257.

41. Cimino, G.; Caristi, C. Acute toxicity of heavy metals to aerobic digestion of waste cheese whey. Biol. Wastes 1990, 33, 201-210. 
42. Ayar, A.; Sert, D.; Akin, N. The trace metal levels in milk and dairy products consumed in middle Anatolia-Turkey. Environ. Monit. Assess. 2009, 152, 1-12.

43. OECD-FAO Agricultural Outlook 2008-2017. Highlights. Paris. Available online: http://www.agri-outlook.org/dataoecd/54/15/40715381.pdf (accessed on 5 September 2012).

44. Karadima, K. Toxicity Estimation of Various Stages of Cheese Making Effluent Treatment Units Using Bioindicators. PhD Dissertation, University of Patra, Patra, Greece, 2009.

45. FAO Food Outlook No. 2. Available online: http://www.fao.org/docrep/009/j8126e/j8126e11.htm (accessed on 5 September 2012).

46. Kotoupas, A.; Rigas, F.; Chalaris, M. Computer-aided process design, economic evaluation and environmental impact assessment for treatment of cheese whey wastewater. Desalination 2007, $213,238-252$.

47. Gekas, V.; Lopez-Leiva, M. Hydrolysis of lactose: A literature review. Process Biochem. 1985, $20,2-12$.

48. Kosikowski, F. Whey utilization and whey products. J. Dairy Sci. 1979, 62, 1149-1160.

49. Yang, S.T.; Silva, E.M. Novel Products and new technologies for use of a familiar carbohydrate, milk lactose. J. Dairy Sci. 1995, 78, 2541-2562.

50. Beaulieu, J.; Dupont C.; Lemieux, P. Whey proteins and peptides: Beneficial effects on immune health. Therapy 2006, 3, 69-78.

51. Yalçin, A.S. Emerging therapeutic potential of whey proteins and peptides. Curr. Pharm. Des. 2006, 12, 1637-1643.

52. Riechel, P.; Weiss, T.; Weiss, M.; Ulber, R.; Heinrich, B.; Scheper, T. Determination of the minor whey protein bovine lactoferrin in cheese whey concentrates with capillary electrophoresis. J. Chromatogr. A 1998, 817, 187-193.

53. Zall, R.R. Trends in whey fractionation and utilization, a global perspective. J. Dairy Sci. 1984, 67, 2621-2629.

54. Kosaric, N.; Asher, Y. The utilization of cheese whey and its components. In Agricultural Feedstock and Waste Treatment and Engineering; Springer: Berlin, Germany, 1985; Volume 32, pp. 25-60.

55. Gänzle, M.G.; Haase, G.; Jelen, P. Lactose: Crystallization, hydrolysis and value-added derivatives. Int. Dairy J. 2008, 18, 685-694.

56. Zadow, J.G. Lactose: Properties and uses. J. Dairy Sci. 1984, 67, 2654-2679.

57. Ling, K.C.; Liebrand, C.B. Whey to Ethanol: A Biofuel Role for Dairy Cooperatives; United States Department of Agriculture: Beltsville, MD, USA, 2008.

58. Pesta, G.; Meyer-Pittroff, R.; Russ, W. Utilization of whey. In Utilization of By-Products and Treatment of Waste in the Food Industry; Oreopoulou, V., Russ, W., Eds.; Springer: New York, NY, USA, 2007; pp. 193-207.

59. Antonopoulou, G.; Stamatelatou, K.; Bebelis, S.; Lyberatos, G. Electricity generation from synthetic substrates and cheese whey using a two chamber microbial fuel cell. Biochem. Eng. J. 2010, 50, 10-15.

60. Stamatelatou, K.; Antonopoulou, G.; Tremouli, A.; Lyberatos, G. Production of Gaseous biofuels and electricity from cheese whey. Ind. Eng. Chem. Res. 2010, 50, 639-644. 
61. Ferchichi, M.; Crabbe, E.; Hintz, W.; Gil, G.-H.; Almadidy, A. Influence of culture parameters on biological hydrogen production by Clostridium saccharoperbutylacetonicum ATCC 27021 . World J. Microbiol. Biotechnol. 2005, 21, 855-862.

62. Yang, P.; Zhang, R.; McGarvey, J.A.; Benemann, J.R. Biohydrogen production from cheese processing wastewater by anaerobic fermentation using mixed microbial communities. Int. J. Hydrog. Energy 2007, 32, 4761-4771.

63. Davila-Vazquez, G.; Alatriste-Mondragón, F.; de León-Rodríguez, A.; Razo-Flores, E. Fermentative hydrogen production in batch experiments using lactose, cheese whey and glucose: Influence of initial substrate concentration and pH. Int. J. Hydrog. Energy 2008, 33, 4989-4997.

64. Azbar, N.; Çetinkaya-Dokgöz, F.T.; Keskin, T.; Korkmaz, K.S.; Syed, H.M. Continuous fermentative hydrogen production from cheese whey wastewater under thermophilic anaerobic conditions. Int. J. Hydrog. Energy 2009, 34, 7441-7447.

65. Rosales-Colunga, L.M.; Razo-Flores, E.; Ordonez, L.G.; Alatriste-Mondragón, F.; de León-Rodríguez, A. Hydrogen production by Escherichia coli DhycA DlacI using cheese whey as substrate. Int. J. Hydrog. Energy 2010, 35, 491-499.

66. Kargi, F.; Eren, N.S.; Ozmihci, S. Hydrogen gas production from cheese whey powder (CWP) solution by thermophilic dark fermentation. Int. J. Hydrog. Energy 2012, 37, 2260-2266.

67. Spachos, T.; Stamatis, A. Thermal analysis and optimization of an anaerobic treatment system of whey. Renew. Energy 2011, 36, 2097-2105.

68. Kelleher, B.P.; Leahy, J.J.; Henihan, A.M.; O’Dwyer, T.F.; Sutton, D.; Leahy, M.J. Advances in poultry litter disposal technology_A review. Bioresour. Technol. 2002, 83, 27-36.

69. Stronach, S.M.; Rudd, T.M.; Lester, J.N. Anaerobic Digestion Processes in Industrial Wastewater Treatment; Springer-Verlag: Berlin, Germany, 1986.

70. Malaspina, F.; Stante, L.; Cellamare, C.M.; Tilche, A. Cheese whey and cheese factory wastewater treatment with a biological anaerobic-Aerobic process. Water Sci. Technol. 1995, 32, 59-72.

71. Van den Berg, L.; Kennedy, K.J. Dairy waste treatment with anaerobic stationary fixed film reactors. In Design of Anaerobic Processes for the Treatment of Industrial and Municipal Wastes; Malina, J.F., Pohland, F.G., Eds.; Technomic Publishing Company: Lancaster, PA, USA, 1992; pp. 89-96

72. Viraraghavan, T.; Kikkeri, S.R. Effect of temperature on anaerobic filter treatment of dairy wastewater. Water Sci. Technol. 1990, 22, 191-198.

73. Viraraghavan, T.; Kikkeri, S.R. Dairy wastewater treatment using anaerobic filters. Can. Agr. Eng. 1991, 33, 143-149.

74. Yan, J.Q.; Lo, K.V.; Liao, P.H. Anaerobic digestion of cheese whey using up-flow anaerobic sludge blanket reactor. Biol. Wastes 1989, 27, 289-305.

75. Wildenauer, F.X.; Winter, J. Anaerobic digestion of high-strength acidic whey in a pH-controlled up-flow fixed film loop reactor. Appl. Microbiol. Biotechnol. 1985, 22, 367-372.

76. Kalyuzhnyi, S.V.; Martinez, E.P.; Martinez, J.R. Anaerobic treatment of high-strength cheese-whey wastewaters in laboratory and pilot UASB-reactors. Bioresour. Technol. 1997, 60, 59-65.

77. Yan, J.Q.; Lo, K.V.; Liao, P.H. Anaerobic digestion of cheese whey using an upflow anaerobic sludge blanket reactor: III. Sludge and substrate profiles. Biomass 1990, 21, 257-271. 
78. Ghaly, A.E. A comparative study of anaerobic digestion of acid cheese whey and dairy manure in a two-stage reactor. Bioresour. Technol. 1996, 58, 61-72.

79. De Haast, J.; Britz, T.J.; Novello, J.C.; Verwey, E.W. Anaerobic digestion of deproteinated cheese whey. J. Dairy Res. 1985, 52, 457-467.

80. Boening, P.H.; Larsen, V.F. Anaerobic fluidized bed whey treatment. Biotechnol. Bioeng. 1982, 24, 2539-2556.

81. Lo, K.V.; Liao, P.H. Digestion of cheese whey with anaerobic rotating biological contact reactors. Biomass 1986, 10, 243-252.

82. Barford, J.P.; Cail, R.G.; Callander, I.J.; Floyd, E.J. Anaerobic digestion of high-strength cheese whey utilizing semicontinuous digesters and chemical flocculant addition. Biotechnol. Bioeng. 1986, 28, 1601-1607.

83. Frigon, J.C.; Breton, J.; Bruneau, T.; Moletta, R.; Guiot, S.R. The treatment of cheese whey wastewater by sequential anaerobic and aerobic steps in a single digester at pilot scale. Bioresour. Technol. 2009, 100, 4156-4163.

84. McHugh, S.; Collins, G.; O'Flaherty, V. Long-term, high-rate anaerobic biological treatment of whey wastewaters at psychrophilic temperatures. Bioresour. Technol. 2006, 97, 1669-1678.

85. Gutiérrez, J.L.R.; Encina, P.A.G.; Fdz-Polanco, F. Anaerobic treatment of cheese-production wastewater using a UASB reactor. Bioresour. Technol. 1991, 37, 271-276.

86. Strydom, J.P.; Mostert, J.F.; Britz, T.J. Anaerobic treatment of a synthetic dairy effluent using a hybrid digester. Water S.A. 1995, 21, 125-130.

87. Patel, C.; Madamwar, D. Biomethanation of salty cheese whey using an anaerobic rotating biological contact reactor. J. Ferment. Bioeng. 1997, 83, 502-504.

88. Patel, C.; Madamwar, D. Biomethanation of salty cheese whey using multichamber anaerobic bioreactor. Energy Environ. 1998, 9, 225-231.

89. Puñal, A.; Méndez-Pampín, R.J.; Lema, J.M. Characterization and comparison of biomasses from single- and multi-fed upflow anaerobic filters. Bioresour. Technol. 1999, 68, 293-300.

90. Calli, B.; Yukselen, M.A. Anaerobic Treatment by a hybrid reactor. Environ. Eng. Sci. 2004, 19, $143-150$.

91. Mockaitis, G.; Ratusznei, S.M.; Rodrigues, J.A.D.; Zaiat, M.; Foresti, E. Anaerobic whey treatment by a stirred sequencing batch reactor (ASBR): Effects of organic loading and supplemented alkalinity. J. Environ. Manag. 2006, 79, 198-206.

92. Patel, P.; Desai, M.; Madamwar, D. Biomethanation of cheese whey using anaerobic upflow fixed film reactor. J. Ferment. Bioeng. 1995, 79, 398-399.

93. Strydom, J.P.; Britz, T.J.; Mostert, J.F. Two-phase anaerobic digestion of three different effluents using a hybrid bioreactor. Water S.A. 1997, 23, 151-156.

94. Comino, E.; Rosso, M.; Riggio, V. Development of a pilot scale anaerobic digester for biogas production from cow manure and whey mix. Bioresour. Technol. 2009, 100, 5072-5078.

95. García, P.A.; Rico, J.L.; Fdz-Polanco, F. Anaerobic treatment of cheese whey in a two-phase uasb reactor. Environ. Technol. 1991, 12, 355-362.

96. Denac, M.; Dunn, I.J. Packed- and fluidized-bed biofilm reactor performance for anaerobic wastewater treatment. Biotechnol. Bioeng. 1988, 32, 159-173. 
97. Schroder, E.W.; de Haast, J. Anaerobic digestion of deproteinated cheese whey in an up-flow sludge blanket reactor. J. Dairy Res. 1989, 56, 129-139.

98. Monroy, H.O.; Vázquez, M.F.; Derramadero, J.C.; Guyot, J.P. Anaerobic-aerobic treatment of cheese wastewater with national technology in Mexico: The case of "El Sauz". Water Sci. Technol. 1995, 32, 149-156.

99. Yilmazer, G.; Yenigün, O. Two-phase anaerobic treatment of cheese whey. Water Sci. Technol. 1999, 40, 289-295.

100. Yang, K.; Yu, Y.; Hwang, S. Selective optimization in thermophilic acidogenesis of cheese-whey wastewater to acetic and butyric acids: Partial acidification and methanation. Water Res. 2003, 37, 2467-2477.

101. Guiot, S.R.; Safi, B.; Frigon, J.C.; Mercier, P.; Mulligan, C.; Tremblay, R.; Samson, R. Performances of a full-scale novel multiplate anaerobic reactor treating cheese whey effluent. Biotechnol. Bioeng. 1995, 45, 398-405.

102. Hakannson, H.; Frostell, B.; Norrman, J. Anaerobic Treatment of Whey and Whey Permeate in Submerged Filters; Inst. Vatten-Luftvardsforsl: Stockholm, Sweden, 1977.

103. Rodgers, M.; Zhan, X.-M.; Dolan, B. Mixing Characteristics and whey wastewater treatment of a novel moving anaerobic biofilm reactor. J. Environ. Sci. Health Part A 2004, 39, 2183-2193.

104. Najafpour, G.D.; Tajallipour, M.; Komeili, M.; Mohammadi, M. Kinetic model for an up-flow anaerobic packed bed bioreactor: Dairy wastewater treatment. Afr. J. Biotechnol. 2009, 8, 3590-3596.

105. Mateescu, C.; Constantinescu, I. Comparative analysisof inoculum biomass for biogas potential in the anaerobic digestion. UPB Sci. Bull. 2011, 73, 99-104.

106. Bouallagui, H.; Ben, C.R.; Marouani, L.; Hamdi, M. Mesophilic biogas production from fruit and vegetable waste in a tubular digester. Bioresour. Technol. 2003, 86, 85-89.

107. Wang, L.K.; Tay, J.H.; Tay, S.T.L.; Hung, Y.T. Environmental Bioengineering, 1st ed.; Humana Press: New York, NY, USA, 2010.

108. Ahring, B.K. Biomethanation II; Springer: Berlin, Germany, 2003.

109. Nayono, S.E. Anaerobic Digestion of Organic Solid Waste for Energy Production. Ph.D. Dissertation, Karlsruhe Institute of Technology, Karlsruhe, Germany, 2009.

110. Chernicharo, C.A.D.L. Anaerobic Reactors; IWA: London, UK, 2007; Volume 4.

111. Qi, Y. Effect of centrifugal dewatering on the regrowth of fecal coliforms and salmonella in anaerobically digested biosolids. Ph.D. Dissertation, University of Delaware, Delaware, NJ, USA, 2008.

112. Kikkeri, S.R.; Viraraghavan, T. Startup of anaerobic filters treating dairy wastewater: Effect of temperature and shock load. J. Environ. Sci. Health Part A 1991, 26, 287-300.

113. Hickey, R.F.; Owens, R.W. Methane generation from high-strength industrial wastes with the anaerobic biological fluidized bed. Biotechnol. Bioeng. Symp. 1981, 11, 399-413.

114. Sutton, P.M.; Li, A. Anitron and oxitron systems: High-rate anaerobic biological treatment systems for industry. In Proceedings of 36th Industrial Waste Conference, Purdue University, West Lafayette, IN, USA, 12-14 May 1981.

115. Shirazi, S.A.M. The new methods for purifying the industrial effluents by submerged biofilm reactors. J. Environ. Prot. 2011, 2, 996-1001. 
116. Ratusznei, S.M.; Rodrigues, J.A.D.; Zaiat, M. Operating feasibility of anaerobic whey treatment in a stirred sequencing batch reactor containing immobilized biomass. Water Sci. Technol. 2003, 48, 179-186.

117. Cocci, A.A.; Burke, B.F.; Landine, R.C.; Blickenstaff, D.L. Anaerobic-aerobic pretreatment of a dairy waste; a case history. Dairy Food Environ. Sanit. 1991, 11, 505-509.

118. Lettinga, G.; van Velsen, A.F.M.; Hobma, S.W.; de Zeeuw, W.; Klapwijk, A. Use of the upflow sludge blanket (USB) reactor concept for biological wastewater treatment, especially for anaerobic treatment. Biotechnol. Bioeng. 1980, 22, 699-734.

119. Yan, J.Q.; Lo, K.V.; Pinder, K.L. Instability caused by high strength of cheese whey in a UASB reactor. Biotechnol. Bioeng. 1993, 41, 700-706.

120. Cammarota, M.C.; Teixeira, G.A.; Freire, D.M.G. Enzymatic pre-hydrolysis and anaerobic degradation of wastewaters with high fat contents. Biotechnol. Lett. 2001, 23, 1591-1595.

121. Elmitwalli, T.A.; Otterpohl, R. Anaerobic biodegradability and treatment of grey water in upflow anaerobic sludge blanket (UASB) reactor. Water Res. 2007, 41, 1379-1387.

122. Kalyuzhnyi, S.; Fedorovich, V.; Lens, P. Dispersed plug flow model for upflow anaerobic sludge bed reactors with focus on granular sludge dynamics. J. Ind. Microbiol. Biotechnol. 2006, 33, 221-237.

123. Zaiat, M.; Rodrigues, J.A.D.; Ratusznei, S.M.; de Camargo, E.F.M.; Borzani, W. Anaerobic sequencing batch reactors for wastewater treatment: A developing technology. Appl. Microbiol. Biotechnol. 2001, 55, 29-35.

124. Damasceno, L.H.S.; Rodrigues, J.A.D.; Ratusznei, S.M.; Zaiat, M.; Foresti, E. Effects of feeding time and organic loading in an anaerobic sequencing batch biofilm reactor (ASBBR) treating diluted whey. J. Environ. Manag. 2007, 85, 927-935.

125. Pohland, F.G.; Ghosh, S. Developments in Anaerobic stabilization of organic wastes-The two-phase concept. Environ. Lett. 1971, 1, 255-266.

126. Alexiou, I.E.; Anderson, G.K.; Evison, L.M. Design of pre-acidification reactors for the anaerobic treatment of industrial wastewaters. Water Sci. Technol. 1994, 29, 199-204.

127. Hall, E.R. Anaerobic treatment of wastewaters in suspended growth and fixed film processes. In Water Quality Management Library; Malina, J.F., Pohland, F.G., Eds.; Technomic Publishing Company Inc.: Lancaster, PA, USA, 1992; Volume 7, pp. 41-119.

128. Cohen, A.; Thiele, J.H.; Zeikus, J.G. Pilot-scale anaerobic treatment of cheese whey by the substrate shuttle process. Water Sci. Technol. 1994, 30, 433-442.

129. Yu, Y.; Hansen, C.L.; Hwang, S. Biokinetics in acidogenesis of highly suspended organic wastewater by adenosine 5' triphosphate analysis. Biotechnol. Bioeng. 2002, 78, 147-156.

130. Frigon, J.C.; Bruneau, T.; Moletta, R.; Guiot, S.R. Coupled anaerobic-aerobic treatment of whey wastewater in a sequencing batch reactor: Proof of concept. Water Sci. Technol. 2007, 55, 201-208.

131. Chan, Y.J.; Chong, M.F.; Law, C.L.; Hassell, D.G. A review on anaerobic-aerobic treatment of industrial and municipal wastewater. Chem. Eng. J. 2009, 155, 1-18.

132. Valbio Canada Inc. Available online: http://www.valbio.ca/en/solutions/for-industries/cheeseproducers.html (accessed on 5 September 2012). 
133. Naskeo Environnement. Available online: http://www.naskeo.com/wastewater_references.html (accessed on 5 September 2012).

134. ESi.info. Available online: http://www.esi.info/detail.cfm/SHE-UK-Ltd/Wheywastewatertreatment-for-cottage-cheese-production/_/R-201.2898 (accessed on 5 September 2012).

135. Procorp Enterprises LLC. Available online: http://procorp.com/wastewater-processes/anaerobicdigestion.html (accessed on 5 September 2012).

136. Navaratnasamy, M.; Edeogu, I.; Papworth, L. Economic Feasibility of Anaerobic Digesters; Practical Inforamtion for Alberta's Agriculture Industry; Alberta Agriculture and Rural Development: Edmonton, AB, Canada, 2008. Available online: http://www1.agric.gov.ab.ca/ \$Department/deptdocs.nsf/all/agdex12280 (accessed on 5 September 2012).

137. Al Seadi, T.; Rutz, D.; Prass1, H.; Köttner, M.; Finsterwalder, T.; Volk, S.; Janssen, R. Biogas Handbook; University of Southern Denmark: Esbjerg, Denmark, 2008.

138. Greer, D. Anaerobic Digestion for smaller dairies. BioCycle 2010, 51, 24-26.

(C) 2012 by the authors; licensee MDPI, Basel, Switzerland. This article is an open access article distributed under the terms and conditions of the Creative Commons Attribution license (http://creativecommons.org/licenses/by/3.0/). 